OAK RIDGE

NATIONAL LABORATORY MANAGED BY UT-BATTELLE FOR THE DEPARTMENT OF ENERGY

\title{
VENUS-2 MOX Core Benchmark: Results of ORNL Calculations Using HELIOS-1.4
}

\author{
R. J. Ellis
}

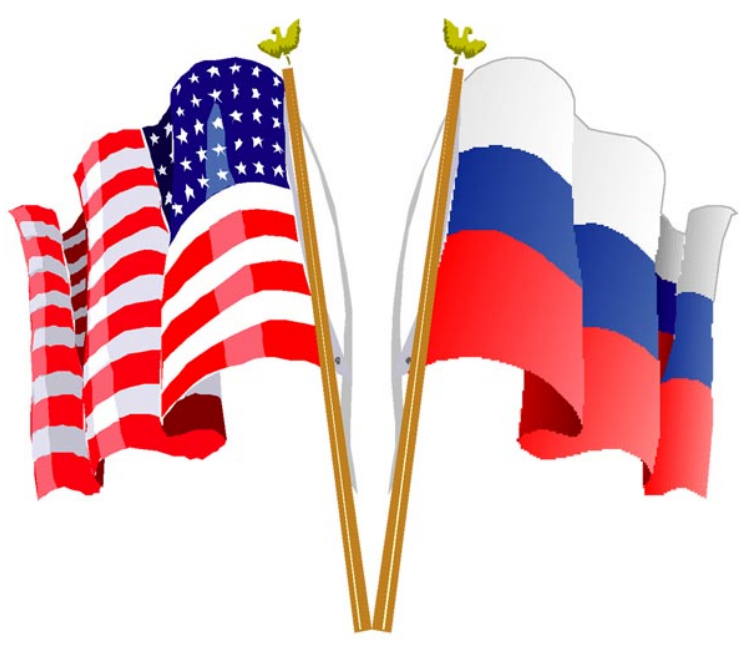

Fissile Materials Disposition Program

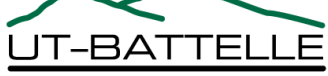




\section{DOCUMENT AVAILABILITY}

Reports produced after January 1,1996 , are generally available free via the U.S. Department of Energy (DOE) Information Bridge.

Web site http://www.osti.gov/bridge

Reports produced before January 1, 1996, may be purchased by members of the public from the following source.

National Technical Information Service

5285 Port Royal Road

Springfield, VA 22161

Telephone 703-605-6000 (1-800-553-6847)

TDD 703-487-4639

Fax 703-605-6900

E-mail info@ntis.fedworld.gov

Web site http://www.ntis.gov/support/ordernowabout.htm

Reports are available to DOE employees, DOE contractors, Energy Technology Data Exchange (ETDE) representatives, and International Nuclear Information System (INIS) representatives from the following source.

Office of Scientific and Technical Information

P.O. Box 62

Oak Ridge, TN 37831

Telephone 865-576-8401

Fax 865-576-5728

E-mail reports@adonis.osti.gov

Web site http://www.osti.gov/contact.html

This report was prepared as an account of work sponsored by an agency of the United States Government. Neither the United States Government nor any agency thereof, nor any of their employees, makes any warranty, express or implied, or assumes any legal liability or responsibility for the accuracy, completeness, or usefulness of any information, apparatus, product, or process disclosed, or represents that its use would not infringe privately owned rights. Reference herein to any specific commercial product, process, or service by trade name, trademark, manufacturer, or otherwise, does not necessarily constitute or imply its endorsement, recommendation, or favoring by the United States Government or any agency thereof. The views and opinions of authors expressed herein do not necessarily state or reflect those of the United States Government or any agency thereof. 


\title{
VENUS-2 MOX CORE BENCHMARK: RESULTS OF ORNL CALCULATIONS USING HELIOS-1.4
}

R. J. Ellis

Date Published: January 2001

\author{
Prepared by \\ OAK RIDGE NATIONAL LABORATORY \\ Oak Ridge, Tennessee 37831 \\ managed by \\ UT-BATTELLE, LLC \\ for the \\ U.S. DEPARTMENT OF ENERGY \\ under contract DE-AC05-00OR22725
}


Page Intentionally Blank 


\section{CONTENTS}

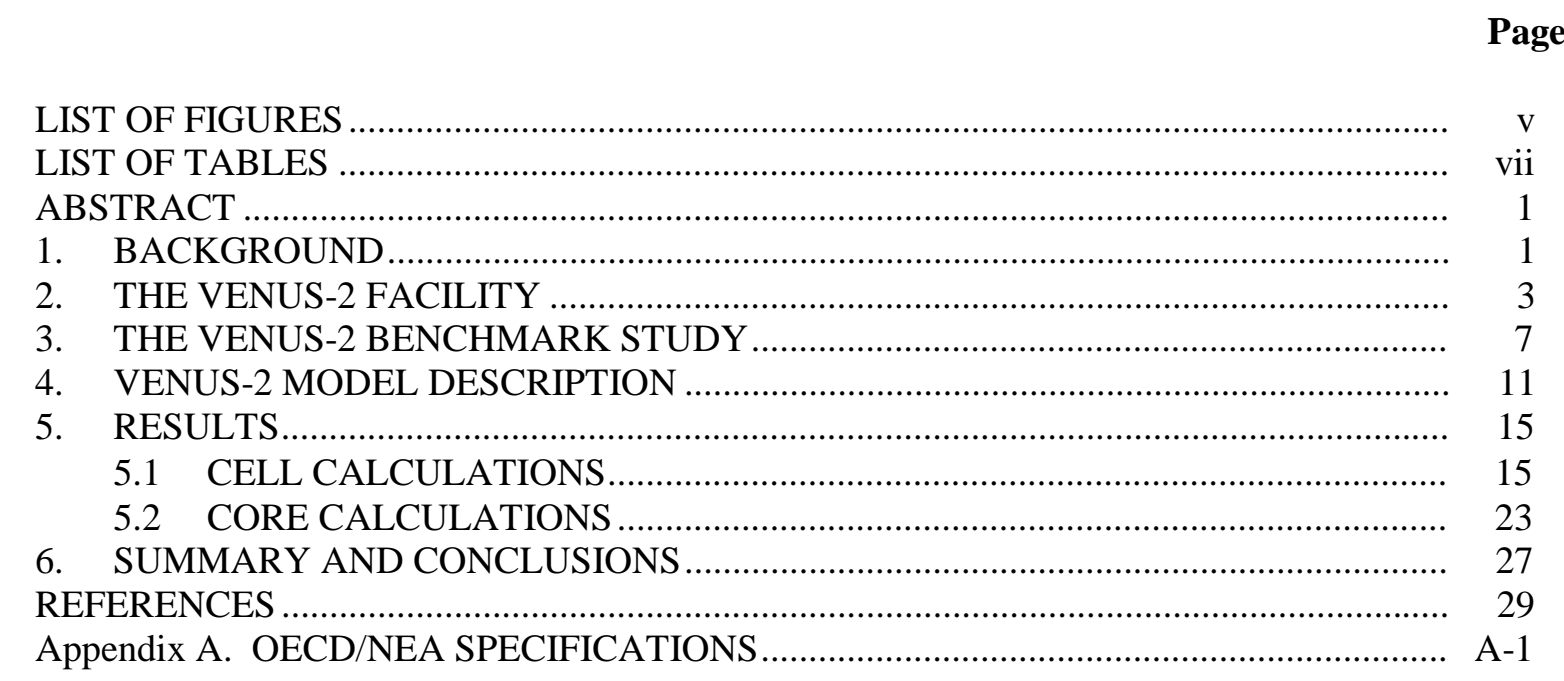


Page Intentionally Blank 


\section{LIST OF FIGURES}

$\begin{array}{ll}\text { Figure } & \text { Page }\end{array}$

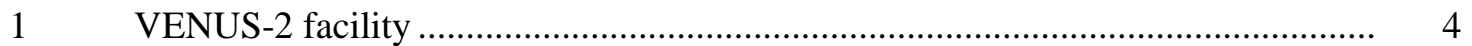

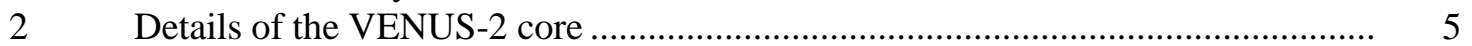

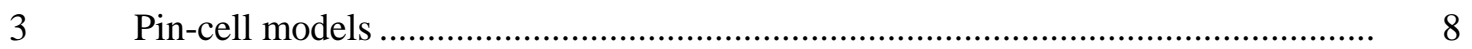

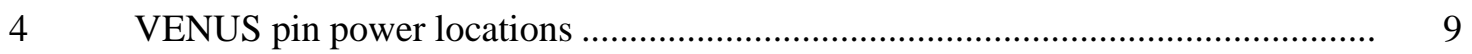

$5 \quad$ ORNL HELIOS code model for VENUS-2 ….................................................. 14 
Page Intentionally Blank 


\section{LIST OF TABLES}

Table

Page

1 VENUS-2 modeling details

Elemental and isotopic concentrations of the VENUS-2 fuel and Pyrex

poison materials.

13

Elemental concentrations of the VENUS-2 cladding materials............................. 13

Elemental concentrations of additional VENUS-2 materials .................................. 14

Cell $\mathrm{k}$ determinations as a function of the number of neutron energy groups ......... 15

The 190-group $\mathrm{k}_{\text {inf }}$ values

15

The $\mathrm{k}_{\mathrm{inf}}$ values of cell calculations

16

Energy integrated reaction rates in $2.0 / 2.7 \mathrm{wt} \% \mathrm{MOX}$ (reactions $/ \mathrm{cm}^{3} / \mathrm{s}$ ) $\left(\mathrm{B}^{2}=2.4 \times 10^{-3} \mathrm{~cm}^{-2}\right)$

Energy integrated reaction rates in $3.3 \mathrm{wt} \% \mathrm{UO}_{2}$ (reactions $/ \mathrm{cm}^{3} / \mathrm{s}$ )

$\left(B^{2}=2.4 \times 10^{-3} \mathrm{~cm}^{-2}\right)$

Energy integrated reaction rates in $4.0 \mathrm{wt} \% \mathrm{UO}_{2}\left(\right.$ reactions $/ \mathrm{cm}^{3} / \mathrm{s}$ )

$\left(\mathrm{B}^{2}=2.4 \times 10^{-3} \mathrm{~cm}^{-2}\right)$

Group $1(\mathrm{E}>5 \mathrm{kV})$ reaction rates in 2.0/2.7 wt \% MOX (reactions $/ \mathrm{cm}^{3} / \mathrm{s}$ )

$\left(\mathrm{B}^{2}=2.4 \times 10^{-3} \mathrm{~cm}^{-2}\right)$

Group $1(\mathrm{E}>5 \mathrm{kV})$ reaction rates in $3.3 \mathrm{wt} \% \mathrm{UO}_{2}\left(\right.$ reactions $\left./ \mathrm{cm}^{3} / \mathrm{s}\right)$

$\left(\mathrm{B}^{2}=2.4 \times 10^{-3} \mathrm{~cm}^{-2}\right)$

Group $1(\mathrm{E}>5 \mathrm{kV})$ reaction rates in $4.0 \mathrm{wt} \% \mathrm{UO}_{2}\left(\right.$ reactions $\left./ \mathrm{cm}^{3} / \mathrm{s}\right)$

$\left(\mathrm{B}^{2}=2.4 \times 10^{-3} \mathrm{~cm}^{-2}\right)$

Group $2(4 \mathrm{eV}<\mathrm{E}<5 \mathrm{kV})$ reaction rates in 2.0/2.7 wt \% MOX

(reactions $\left./ \mathrm{cm}^{3} / \mathrm{s}\right)\left(\mathrm{B}^{2}=2.4 \times 10^{-3} \mathrm{~cm}^{-2}\right)$.

Group $2(4 \mathrm{eV}<\mathrm{E}<5 \mathrm{kV})$ reaction rates in $3.3 \mathrm{wt} \% \mathrm{UO}_{2}\left(\right.$ reactions $\left./ \mathrm{cm}^{3} / \mathrm{s}\right)$

$\left(\mathrm{B}^{2}=2.4 \times 10^{-3} \mathrm{~cm}^{-2}\right)$.

Group $2(4 \mathrm{eV}<\mathrm{E}<5$
$\left(\mathrm{B}^{2}=2.4 \times 10^{-3} \mathrm{~cm}^{-2}\right)$

$\mathrm{kV})$ reaction rates in $4.0 \mathrm{wt} \% \mathrm{UO}_{2}\left(\right.$ reactions $\left./ \mathrm{cm}^{3} / \mathrm{s}\right)$

Group $3(\mathrm{E}<4 \mathrm{eV})$ reaction rates in $2.0 / 2.7 \mathrm{wt} \% \mathrm{MOX}\left(\right.$ reactions $\left./ \mathrm{cm}^{3} / \mathrm{s}\right)$

$\left(\mathrm{B}^{2}=2.4 \times 10^{-3} \mathrm{~cm}^{-2}\right)$

Group $3(\mathrm{E}<4 \mathrm{eV})$ reaction rates in $3.3 \mathrm{wt} \% \mathrm{UO}_{2}\left(\mathrm{reactions} / \mathrm{cm}^{3} / \mathrm{s}\right)$

$\left(\mathrm{B}^{2}=2.4 \times 10^{-3} \mathrm{~cm}^{-2}\right)$

Group $3(\mathrm{E}<4 \mathrm{eV})$ reaction rates in $4.0 \mathrm{wt} \% \mathrm{UO}_{2}\left(\mathrm{reactions} / \mathrm{cm}^{3} / \mathrm{s}\right)$

$\left(\mathrm{B}^{2}=2.4 \times 10^{-3} \mathrm{~cm}^{-2}\right)$

Energy integrated reaction rates in $2.0 / 2.7$ wt $\%$ MOX (reactions $/ \mathrm{cm}^{3} / \mathrm{s}$ )

$\left(\mathrm{B}^{2}=0\right)$

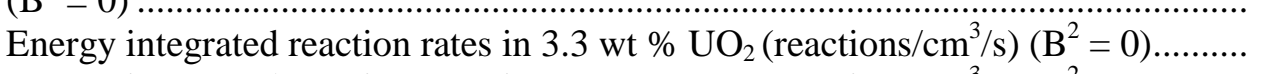

Energy integrated reaction rates in $4.0 \mathrm{wt} \% \mathrm{UO}_{2}\left(\right.$ reactions $\left./ \mathrm{cm}^{3} / \mathrm{s}\right)\left(\mathrm{B}^{2}=0\right) \ldots$

Group $1(\mathrm{E}>5 \mathrm{kV})$ reaction rates in 2.0/2.7 wt $\% \mathrm{MOX}\left(\right.$ reactions $\left./ \mathrm{cm}^{3} / \mathrm{s}\right)$

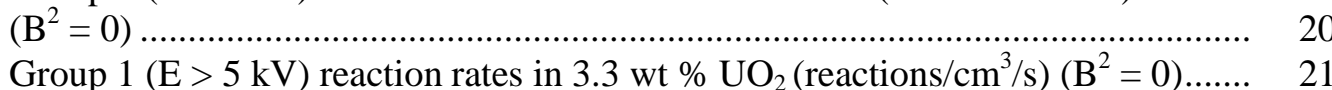

Group $1(\mathrm{E}>5 \mathrm{kV})$ reaction rates in $4.0 \mathrm{wt} \% \mathrm{UO}_{2}\left(\right.$ reactions $\left./ \mathrm{cm}^{3} / \mathrm{s}\right)\left(\mathrm{B}^{2}=0\right) \ldots \ldots . .21$

Group $2(4 \mathrm{eV}<\mathrm{E}<5 \mathrm{kV})$ reaction rates in 2.0/2.7 wt \% MOX

(reactions $\left./ \mathrm{cm}^{3} / \mathrm{s}\right)\left(\mathrm{B}^{2}=0\right)$

Group $2(4 \mathrm{eV}<\mathrm{E}<5 \mathrm{kV})$ reaction rates in $3.3 \mathrm{wt} \% \mathrm{UO}_{2}\left(\right.$ reactions $\left./ \mathrm{cm}^{3} / \mathrm{s}\right)$

$\left(\mathrm{B}^{2}=0\right)$

Group $2(4 \mathrm{eV}<\mathrm{E}<5 \mathrm{kV})$ reaction rates in $4.0 \mathrm{wt} \% \mathrm{UO}_{2}\left(\right.$ reactions $\left./ \mathrm{cm}^{3} / \mathrm{s}\right)$

$\left(\mathrm{B}^{2}=0\right)$ 
29 Group $3(\mathrm{E}<4 \mathrm{eV})$ reaction rates in $2.0 / 2.7 \mathrm{wt} \% \mathrm{MOX}\left(\right.$ reactions $\left./ \mathrm{cm}^{3} / \mathrm{s}\right)$ $\left(\mathrm{B}^{2}=0\right)$

$30 \quad$ Group $3(\mathrm{E}<4 \mathrm{eV})$ reaction rates in $3.3 \mathrm{wt} \% \mathrm{UO}_{2}\left(\mathrm{reactions} / \mathrm{cm}^{3} / \mathrm{s}\right)\left(\mathrm{B}^{2}=0\right) \ldots \ldots . \quad 22$

31 Group $3(\mathrm{E}<4 \mathrm{eV})$ reaction rates in $4.0 \mathrm{wt} \% \mathrm{UO}_{2}\left(\right.$ reactions $\left./ \mathrm{cm}^{3} / \mathrm{s}\right)\left(\mathrm{B}^{2}=0\right) \ldots \ldots . \quad 22$

32 OECD/NEA VENUS-2 core calculation: ORNL VENUS- 2 model for HELIOS

33 Calculated pin power (fission rate) distribution

34 ORNL VENUS-2 pin power calculations with HELIOS-1.4 in 190-group: the effect of an improved outer model

ORNL VENUS-2 core $\mathrm{k}_{\text {eff }}$ calculations with HELIOS-4: effect of improved outer water model 


\title{
VENUS-2 MOX CORE BENCHMARK: RESULTS OF ORNL CALCULATIONS USING HELIOS-1.4
}

\author{
R. J. Ellis
}

\begin{abstract}
The Task Force on Reactor-Based Plutonium Disposition, now an Expert Group, was set up through the Organization for Economic Cooperation and Development/Nuclear Energy Agency to facilitate technical assessments of burning weapons-grade plutonium mixed-oxide (MOX) fuel in U.S. pressurized-water reactors and Russian VVER nuclear reactors. More than ten countries participated to advance the work of the Task Force in a major initiative, which was a blind benchmark study to compare code benchmark calculations against experimental data for the VENUS-2 MOX core at SCK-CEN in Mol, Belgium. At the Oak Ridge National Laboratory, the HELIOS-1.4 code was used to perform a comprehensive study of pin-cell and core calculations for the VENUS-2 benchmark.
\end{abstract}

\section{BACKGROUND}

The issue of excess plutonium produced during the operation of commercial nuclear power plants (NPPs) has become important to the international nuclear community. Therefore, many countries reuse plutonium recovered from nuclear waste in the form of mixed-oxide (MOX) uranium and plutonium fuel in existing power plants, a well-established technology that has been used for many years. The recommended loading limit of a plutonium assembly in a pressurizedwater reactor (PWR) core is $30 \%$ of the total core loading to avoid any problems that might be caused by power peaking or degradation of safety parameters associated with high plutonium loading.

It is necessary to validate both the basic nuclear data and calculational methods to better understand the behavior of MOX fuel in various scenarios and to identify possible improvements in nuclear data and physics modeling methods.

For this purpose, the Organization for Economic Cooperation and Development (OECD)/ Nuclear Energy Agency (NEA) Working Party on the Physics of Plutonium Fuels and Innovative Fuel Cycles (WPPR) was set up in 1993. Since that time, WPPR has reported on physics benchmarks relating to multiple recycling of plutonium in PWRs and boiling-water reactors (BWRs) and burning/multirecycling of plutonium in fast reactors. These activities were entirely concerned with theoretical benchmark calculations. In 1999, a Task Force on Reactor-Based Plutonium Disposition (TFRPD), now an Expert Group, was set up to undertake a technical evaluation by assessing the implications of moving from low-enriched uranium (LEU) to weapons-grade (WG) MOX in Western PWR and Russian VVER reactors.

Theoretical benchmarks have been performed so far, but there was a need for comparison with actual experimental data. Consequently, the VENUS-2 experimental data have been released for this purpose by SCK-CEN. In a major initiative, a blind benchmark study ${ }^{1}$ was completed in which more than ten countries participated in comparing code calculations to experimental VENUS-2 data. 
Page Intentionally Blank 


\section{THE VENUS-2 FACILITY}

The VENUS critical facility is a "zero power" critical reactor located at SCK-CEN in Mol, Belgium. VENUS is an acronym for "VULCAIN Experimental Nuclear Study;" VULCAIN was the name of a marine reactor concept from the early 1960s.

The central part of the VENUS-2 MOX core consists of $\mathrm{UO}_{2}$ fuel pins with MOX fuel pins loaded on the periphery of the core (Fig. 1). The VENUS-2 core diagram in Fig. 1 was borrowed from Ref. 1. Figure 2 presents a new diagram of the VENUS- 2 core with fuel and poison pin placements more clearly shown. The diagram in Fig. 2 is courtesy of Ref. 2. The VENUS-2 core configuration is called a uranium-plutonium core and is representative of low neutron leakage configurations.

The VENUS- 2 core comprises 12 " 15 by 15 " subassemblies, instead of those of " 17 by 17 ," but the pin-to-pin pitch remains typical of the 17 by 17 subassembly. The central part of the core (four 15 by 15 assemblies) consists of fuel pins $3.3 \mathrm{wt} \%$ enriched in ${ }^{235} \mathrm{U}$. There are 40 Pyrex poison pins in the core. Of the eight assemblies on the periphery of the core, all of which contain fuel pins $4.0 \mathrm{wt} \%$ enriched in ${ }^{235} \mathrm{U}$, eight rows of the most external fuel pins have been replaced by MOX fuel pins $\left(\mathrm{UO}_{2}-\mathrm{PuO}_{2}\right)$ enriched $2.0 \mathrm{wt} \%$ in ${ }^{235} \mathrm{U}$ and $2.7 \mathrm{wt} \%$ in high-grade plutonium with the major plutonium isotopes as shown in Fig. 1. The fuel pin locations can be seen through examination of Fig. 2.

The VENUS-2 experimental results for the core physics study comprise the axial buckling measurement and pin power distribution measurements in 1/8 of the core. Apart from the pin power distribution measurements, reaction rates at several important positions in the reactor were also measured using ${ }^{58} \mathrm{Ni},{ }^{115} \mathrm{In},{ }^{103} \mathrm{Rh},{ }^{64} \mathrm{Zn},{ }^{237} \mathrm{~Np}$, and ${ }^{27} \mathrm{Al}$ detectors/foils. The VENUS-2 experimental data can be used both for pressure vessel dosimetry studies and core physics analysis, though the latter is the focus of the present reactor physics benchmark calculations and this report. 
SCK/CEN-Mol (Belgium)

VENUS-2 LWR-PVS Benchmark Experiment

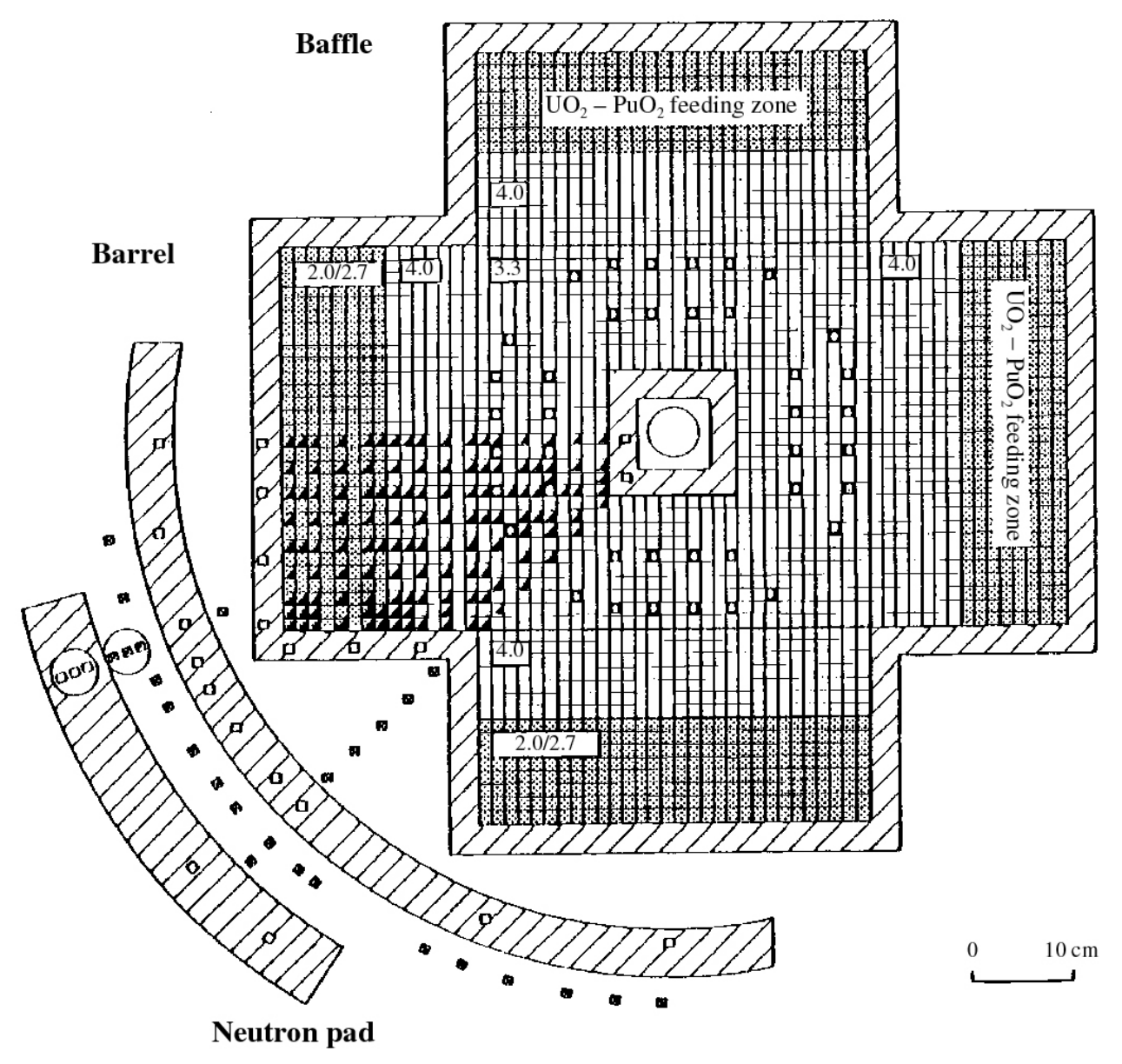

$\mathrm{UO}_{2}-\mathrm{PuO}_{2}$ fuel lattice (Pitch: $1.26 \mathrm{~cm}$ )

$2.0 \%$ uranium enriched $2.7 \%$ total plutonium (1)

III $\mathrm{UO}_{2}$ fuel lattice (Pitch: $1.26 \mathrm{~cm}$ ) $3.3 \%$ and $4.0 \%$ uranium enriched

D Pyrex rods (2)

a Fuel rod measured for determination of power map in the $0-45^{\circ}$ sector

$\square \quad$ Measurement locations in steel structures

囚 Measurement locations in water

Thimble for gamma or neutron spectrometer

(1) Plutonium composition: $-79.37 \%{ }^{239} \mathrm{Pu}$ $-17.14 \%{ }^{240} \mathrm{Pu}$ $-3.05 \%{ }^{241} \mathrm{Pu}$

(2) Amount has been adjusted for criticality

Fig. 1. VENUS-2 facility. 
ORNL 2000-1339C EFG

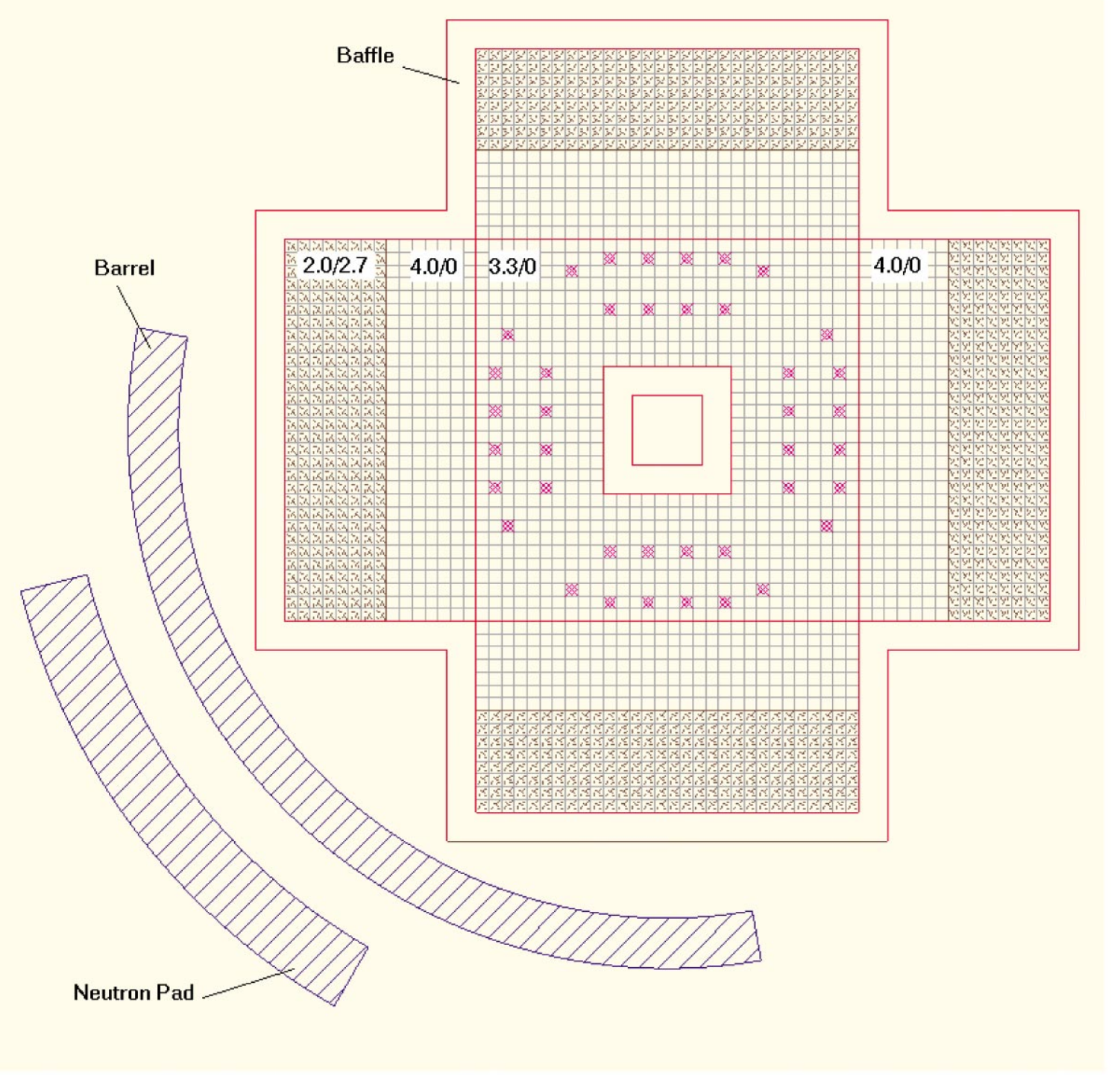

Fig. 2. Details of the VENUS-2 core. 
Page Intentionally Blank 


\section{THE VENUS-2 BENCHMARK STUDY}

The objective of the benchmark was to validate and compare the nuclear data sets and production codes used for MOX-fueled system calculations in NEA member countries. The comparison with experimental data would allow identification of discrepancies between calculations and measurements, quantification of the relative merits of the different calculational methods, and possibly identification of the origin of any observed discrepancies.

The VENUS-2 MOX benchmark exercise was a blind test. The measured pin power values at specified VENUS locations were not revealed to the participants. A number of institutions worldwide participated in the benchmark study. The calculated pin power distributions by the diverse computer codes at the different institutions were compared with the experimental results only after all the results were submitted. The computer codes used by the participants included deterministic codes, Monte Carlo codes, and diffusion codes. Various nuclear data sets such as ENDF/B-V, ENDF/B-VI, JEF-1, JEF-2.2, and JENDL-3.2 were also investigated. For power distribution calculations, the deterministic codes included two versions of the collision probability code HELIOS, a collision probability code BOXER, and the two-dimensional (2-D) SN code DORT. The continuous energy Monte Carlo codes were MCNP-4B, MVP, and MCU-B. A diffusion nodal code named GNOMER was also used.

At Oak Ridge National Laboratory (ORNL), the VENUS-2 benchmark calculations were completed using the $n, \gamma$-transport lattice physics code HELIOS-1.4. HELIOS ${ }^{3-5}$ is a code from Studsvik Scandpower, Inc. The results of the ORNL blind benchmark calculations ${ }^{6}$ were delivered to the OECD/NEA before the VENUS-2 experimental data were released to the participants.

The specifications for the VENUS-2 benchmark study and a full description of the core were presented in Ref. 1. The experimental axial buckling measurements were provided for the 2-D calculations. Apart from the geometry and material data, the isotopic concentrations of each medium were also provided to minimize the discrepancies from the atomic density calculations. To obtain vertical bucklings representative of the core, six fuel pins (three at $4.0 \mathrm{wt} \%$ and three at $3.3 \mathrm{wt} \%{ }^{235} \mathrm{U}$ ) were measured axially by gamma-scanning after an irradiation of 8 hours at $90 \%$ of the VENUS maximum power. The results requested from the participants hours are summarized as follows:

1. Cell calculations

For each type of fuel cell ( $3.3 \mathrm{wt} \% \mathrm{UO}_{2}, 4.0 \mathrm{wt} \% \mathrm{UO}_{2}$, and 2.0/2.7 wt $\left.\% \mathrm{MOX}\right)$, the following are calculated: the $\mathrm{k}_{\mathrm{inf}}$ values, and the absorption and fission reaction rates per specified isotope (energy integrated and in three groups with 5-keV and 4-eV boundaries). Figure 3 shows the three pin-cell models as prepared for HELIOS for this work.

\section{Core calculations}

For the VENUS-2 reactor system, $\mathrm{k}_{\text {eff }}$ is to be determined. The normalized pin-power distributions (fission rates) are to be determined by pin for $1 / 8$ of the core, including the fuel pins in the diagonal from pin 6 to pin 100 as seen in Fig. 4. Normalization is to be made by $\mathrm{OECD} / \mathrm{NEA}$ to a core average fission rate $=1$ fission $/ \mathrm{s} /$ fuel $\mathrm{pin}$.

The average fission rate in the core corresponding to the absolute reference irradiation in VENUS-2 is $1.87 \mathrm{E}+08$ fissions $/ \mathrm{cm} / \mathrm{s}$ at the midplane. This average fission rate corresponds to a power level of $595 \mathrm{~W}$. The 128 fuel rods (44 with $3.3 \mathrm{wt} \% \mathrm{UO}_{2}, 38$ with $4.0 \mathrm{wt} \% \mathrm{UO}_{2}$, and 46 with 2.0/2.7 wt \% MOX) were assessed after an irradiation of 13.5 hours at $90 \%$ of the VENUS maximum power. As mentioned above, the measured pin power values were normalized to a core-averaged fission rate $=1$ fission/s/pin (or to a total core fission rate of 2560 fissions/s). The experimental data were taken from the gamma activity of the ${ }^{140} \mathrm{La}$ (fission yields $\sim 6.3 \%$ for ${ }^{235} \mathrm{U}$ and $\sim 5.5 \%$ for ${ }^{239} \mathrm{Pu}$, energy $\sim 1.6 \mathrm{MeV}$, and effective half-life of $\sim 12.8 \mathrm{~d}$ ). 
Windmill Cell Geometry
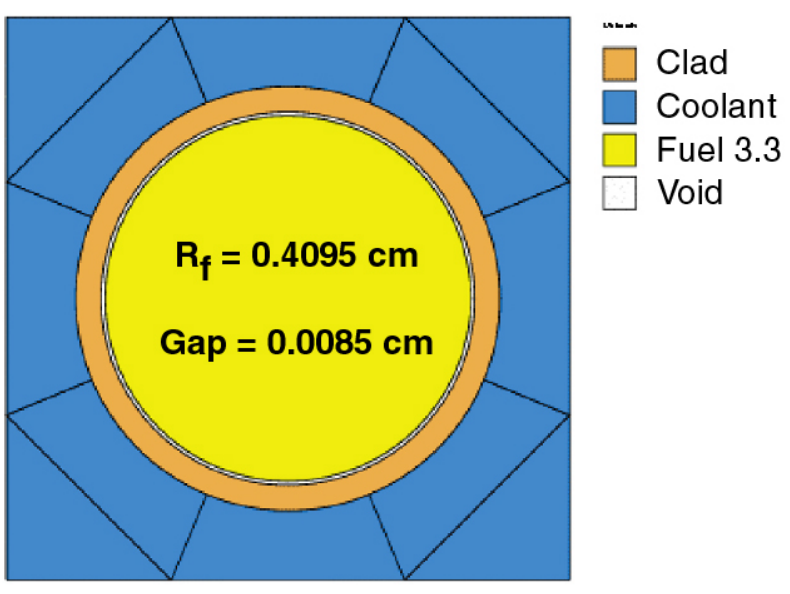

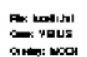

$=0 x+x$
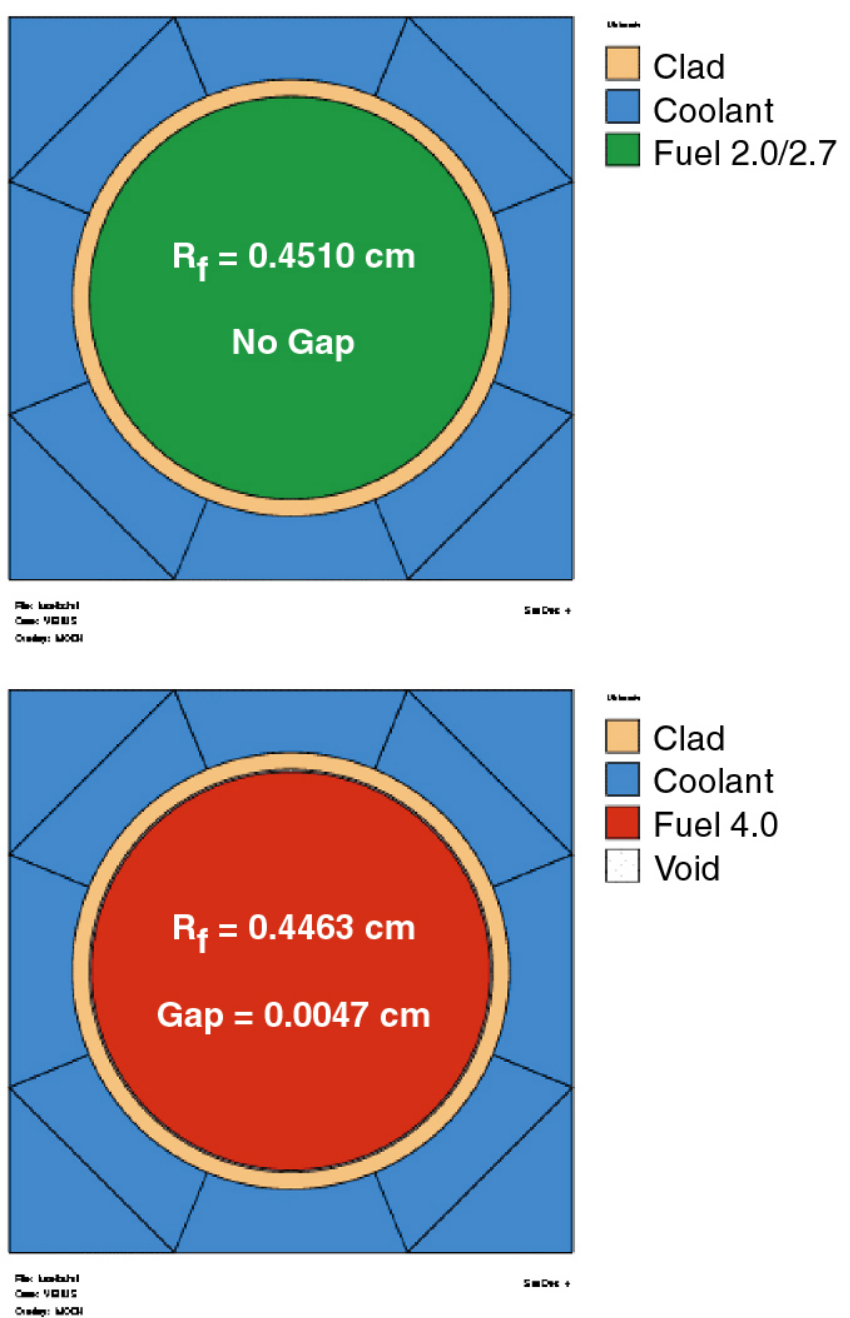

Fig. 3. Pin-cell models. 
ORNL 2000-1341C EFG

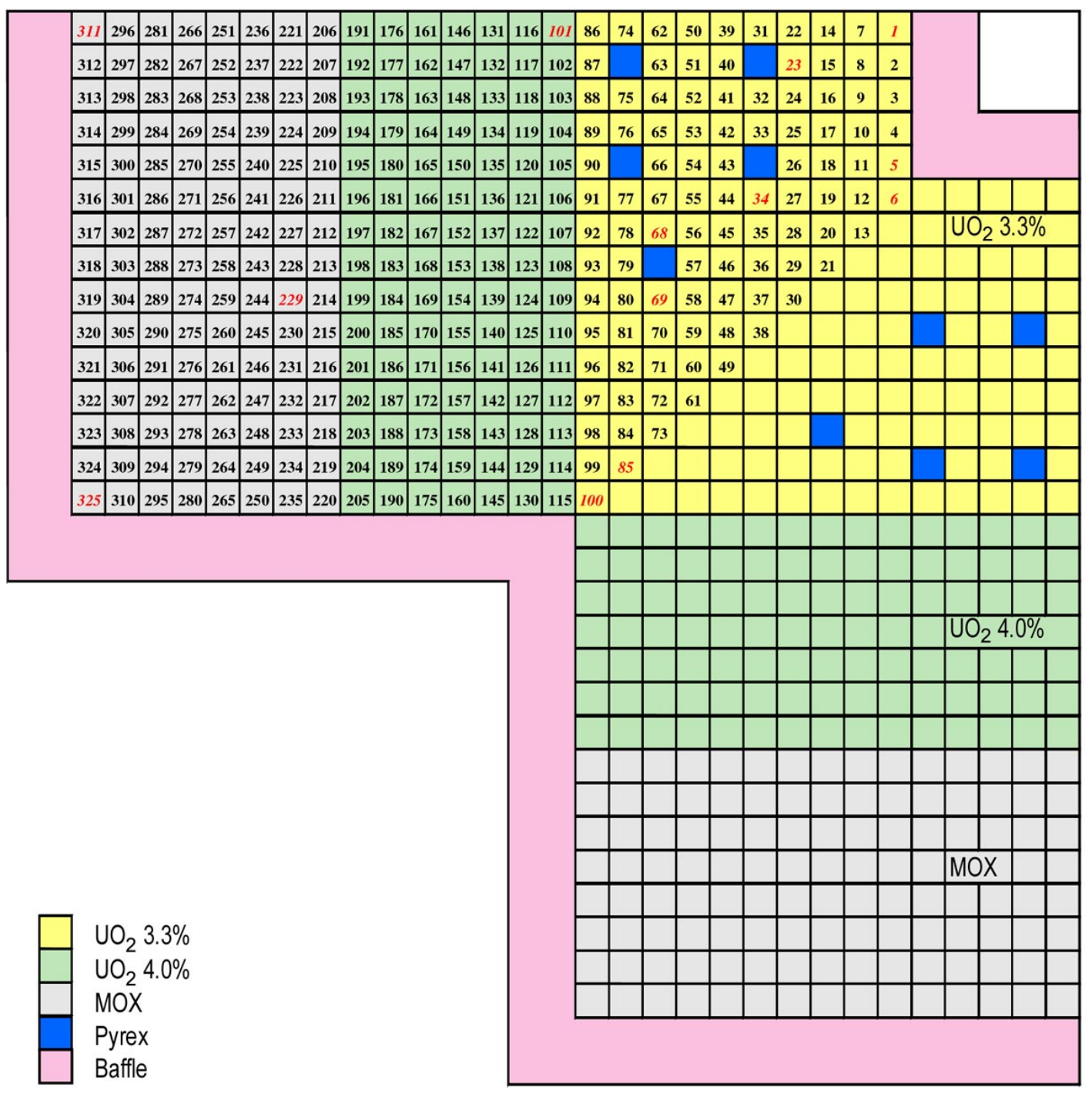

Fig. 4. VENUS pin power locations. 
Page Intentionally Blank 


\section{VENUS-2 MODEL DESCRIPTION}

For this benchmark study, HELIOS-1.4 was used to model the VENUS-2 reactor system for the core calculations and for the individual fuel pin cells for the cell calculations. For the ORNL results, HELIOS-1.4 was used with nuclear data libraries (based on ENDF/B-VI) in 34-, 89-, and 190-neutron-energy groups. The code uses neutron and $\gamma$-transport calculations for lattice physics calculations in a generalized 2-D geometry. Fuel depletion (burnup) can be modeled with HELIOS, but this was not required for the VENUS-2 calculations because of the low power level of the experimental facility. The main calculational method utilized in HELIOS is referred to as CCCP: current coupling between structures and collision probability transport methods within structures.

Table 1 presents the major modeling data for the VENUS- 2 reactor system. These data and other information used in the VENUS-2 HELIOS model input are from Ref. 1. The compositions of the materials in the VENUS-2 reactor are presented in Tables 2-4. Table 2 shows the elemental and isotopic (where appropriate) atom densities for the three types of fuel and the Pyrex neutron poison material. Tables 3 and 4 show the elemental compositions of the cladding, water, and reactor structural materials.

The pin cells for the three types of fuel are shown schematically in Fig. 3. In the cell calculations, $\mathrm{k}_{\mathrm{inf}}$ and reaction rate results for three ranges of neutron energy $(0-4 \mathrm{eV}, 4 \mathrm{eV}-5 \mathrm{keV}$, $>5 \mathrm{keV}$ ) were calculated for the individual pin-cell models: $3.0 \mathrm{wt} \% \mathrm{UO}_{2}, 4.0 \mathrm{wt} \% \mathrm{UO}_{2}$, and 2.0/2.7 wt \% MOX. The actual energy boundaries used with HELIOS-1.4 were the ones closest to the specified library values: $3.928 \mathrm{eV}$ and $4.881 \mathrm{keV}$.

For the core calculations and the pin power (fission rate) determinations, the 2-D layout of the VENUS-2 system (as shown in Fig. 2) was represented in a HELIOS model as a 1/8-core with specular reflection at the radial boundaries and vacuum boundary conditions at the outer edge. Figure 5 represents the most recent ORNL HELIOS model of VENUS-2. The ORNL VENUS-2 HELIOS model is much more detailed than the resolution in the Fig. 5 diagram permits. For example, the "windmill" cell coolant partition pattern shown in Fig. 3 is used in the modeling for all the fuel pin and Pyrex poison pin sites. Each fuel pin is modeled with four concentric radial zones. The Pyrex poison pins are annular in shape with void in the inner portion. The Pyrex poison region is represented with two annular zones.

Appendix A provides a questionnaire presented to all the benchmark participants. The ORNL (HELIOS) responses are also included. This appendix provides additional information on the modeling methodologies used by ORNL to represent VENUS-2. 
Table 1. VENUS-2 modeling details

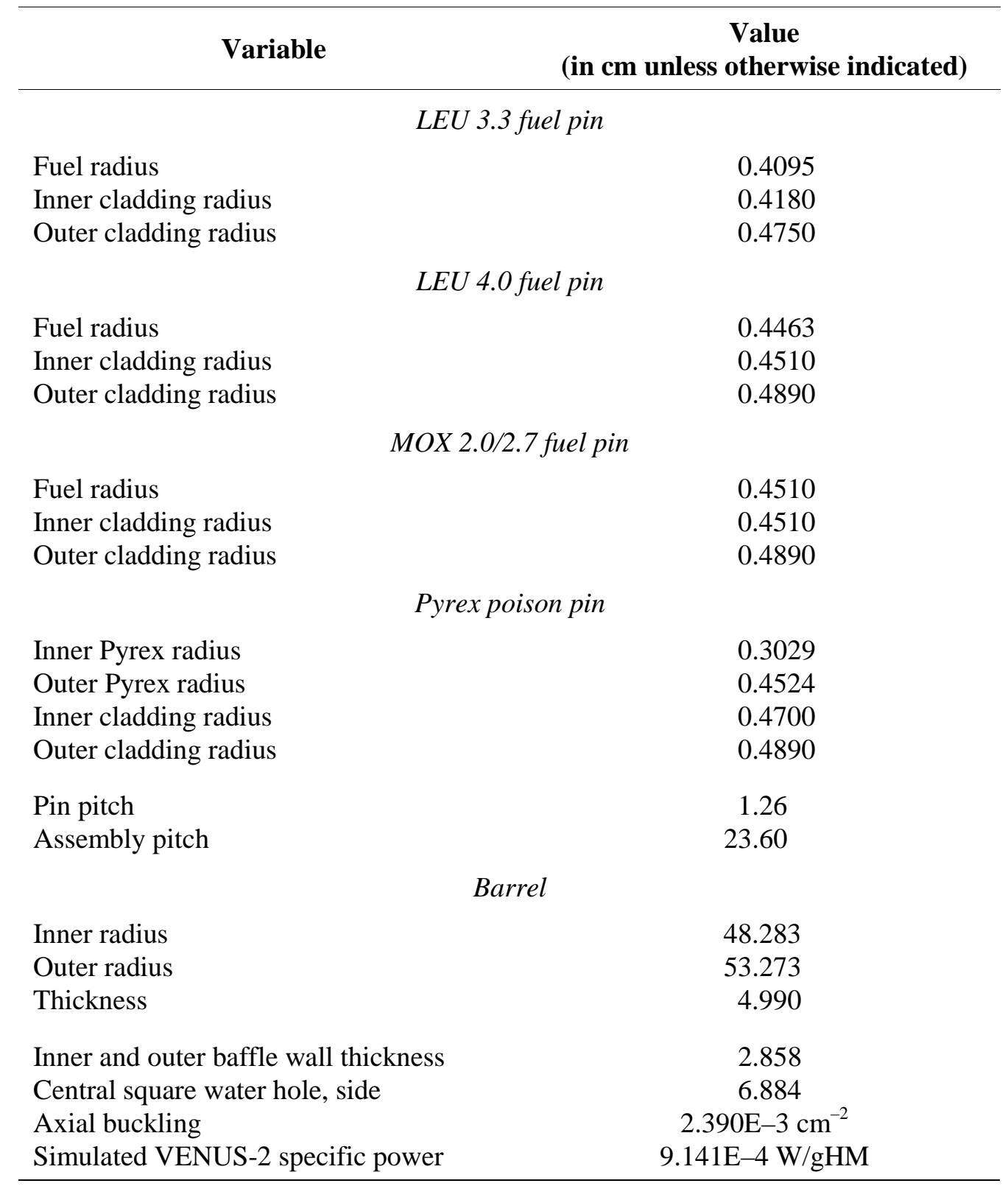


Table 2. Elemental and isotopic concentrations of the VENUS-2 fuel and Pyrex poison materials (atoms/b-cm)

\begin{tabular}{lcccc}
\hline & Fuel 3.3 & Fuel 4.0 & $\begin{array}{c}\text { Fuel 2.0/2.7 } \\
\text { (MOX) }\end{array}$ & $\begin{array}{c}\text { Pyrex } \\
\text { poison }\end{array}$ \\
\hline${ }^{234} \mathrm{U}$ & $6.74213 \mathrm{E}-06$ & $7.17988 \mathrm{E}-06$ & $3.31550 \mathrm{E}-06$ & \\
${ }^{235} \mathrm{U}$ & $7.65322 \mathrm{E}-04$ & $9.27556 \mathrm{E}-04$ & $4.13082 \mathrm{E}-04$ & \\
${ }^{236} \mathrm{U}$ & $3.68820 \mathrm{E}-06$ & $5.28177 \mathrm{E}-06$ & $2.67097 \mathrm{E}-06$ & \\
${ }^{238} \mathrm{U}$ & $2.20912 \mathrm{E}-02$ & $2.18426 \mathrm{E}-02$ & $1.99605 \mathrm{E}-02$ & \\
${ }^{239} \mathrm{Pu}$ & & & $4.47077 \mathrm{E}-04$ & \\
${ }^{240} \mathrm{Pu}$ & & & $9.61437 \mathrm{E}-05$ & \\
${ }^{241} \mathrm{Pu}$ & & & $1.70372 \mathrm{E}-05$ & \\
${ }^{242} \mathrm{Pu}$ & & & $2.44766 \mathrm{E}-06$ & \\
${ }^{241} \mathrm{Am}$ & & & $4.18948 \mathrm{E}-07$ & \\
& & & & \\
$\mathrm{O}$ & $4.57338 \mathrm{E}-02$ & $4.55653 \mathrm{E}-02$ & $4.18853 \mathrm{E}-02$ & $4.52326 \mathrm{E}-02$ \\
& & & & $1.74973 \mathrm{E}-02$ \\
$\mathrm{Si}$ & & & & $1.12120 \mathrm{E}-03$ \\
${ }^{10} \mathrm{~B}$ & $3.64042 \mathrm{E}-09$ & & & $5.51296 \mathrm{E}-03$ \\
${ }^{11} \mathrm{~B}$ & $1.46531 \mathrm{E}-08$ & & & $3.80342 \mathrm{E}-04$ \\
$\mathrm{Al}$ & & & & $1.48608 \mathrm{E}-03$ \\
$\mathrm{Fe}$ & & & & $3.21198 \mathrm{E}-04$ \\
$\mathrm{Na}$ & & & & \\
$\mathrm{K}$ & & & & \\
\hline
\end{tabular}

Table 3. Elemental concentrations of the VENUS-2 cladding materials (atoms/b-cm)

\begin{tabular}{lcccc}
\hline & $\begin{array}{c}\text { Fuel 3.3 pin } \\
\text { cladding }\end{array}$ & $\begin{array}{c}\text { Fuel 4.0 pin } \\
\text { cladding }\end{array}$ & $\begin{array}{c}\text { MOX pin } \\
\text { cladding }\end{array}$ & $\begin{array}{c}\text { Pyrex pin } \\
\text { cladding }\end{array}$ \\
\hline $\mathrm{C}$ & & $1.58254 \mathrm{E}-04$ & $1.58254 \mathrm{E}-04$ & $1.18827 \mathrm{E}-04$ \\
$\mathrm{Mn}$ & & $1.11582 \mathrm{E}-03$ & $1.11582 \mathrm{E}-03$ & $7.53397 \mathrm{E}-04$ \\
$\mathrm{P}$ & & $3.06841 \mathrm{E}-05$ & $3.06841 \mathrm{E}-05$ & $4.91240 \mathrm{E}-04$ \\
$\mathrm{~S}$ & & $2.22292 \mathrm{E}-05$ & $2.22292 \mathrm{E}-05$ & \\
$\mathrm{Si}$ & & $2.28418 \mathrm{E}-04$ & $2.28418 \mathrm{E}-04$ & \\
$\mathrm{Cr}$ & $7.69688 \mathrm{E}-05$ & $1.67247 \mathrm{E}-02$ & $1.67247 \mathrm{E}-02$ & $1.68355 \mathrm{E}-02$ \\
$\mathrm{Ni}$ & & $8.12063 \mathrm{E}-03$ & $8.12063 \mathrm{E}-03$ & $7.70038 \mathrm{E}-03$ \\
$\mathrm{Mo}$ & & $6.53811 \mathrm{E}-05$ & $6.53811 \mathrm{E}-05$ & $3.47117 \mathrm{E}-05$ \\
$\mathrm{Fe}$ & $1.43323 \mathrm{E}-04$ & $5.95953 \mathrm{E}-02$ & $5.95953 \mathrm{E}-02$ & $6.03471 \mathrm{E}-02$ \\
$\mathrm{Sn}$ & $4.75354 \mathrm{E}-04$ & & & \\
$\mathrm{O}$ & $3.00167 \mathrm{E}-04$ & & & \\
$\mathrm{Zr}$ & $4.30680 \mathrm{E}-02$ & & & \\
\hline
\end{tabular}


Table 4. Elemental concentrations of additional VENUS-2 materials (atoms/b-cm)

\begin{tabular}{|c|c|c|c|}
\hline & Water & Baffle & Barrel \\
\hline $\mathrm{C}$ & & $2.33752 \mathrm{E}-04$ & $5.94134 \mathrm{E}-05$ \\
\hline $\mathrm{Mn}$ & & $1.43008 \mathrm{E}-03$ & $1.12836 \mathrm{E}-03$ \\
\hline $\mathrm{P}$ & & $4.60909 \mathrm{E}-05$ & $4.30073 \mathrm{E}-05$ \\
\hline $\mathrm{S}$ & & $1.92924 \mathrm{E}-05$ & 7.41827E-06 \\
\hline $\mathrm{Si}$ & & $4.82892 \mathrm{E}-04$ & $8.68986 \mathrm{E}-04$ \\
\hline $\mathrm{Cr}$ & & $1.49819 \mathrm{E}-02$ & $1.68940 \mathrm{E}-02$ \\
\hline $\mathrm{Ni}$ & & $7.06993 \mathrm{E}-03$ & $8.26696 \mathrm{E}-03$ \\
\hline Mo & & $2.25187 \mathrm{E}-04$ & $2.35048 \mathrm{E}-04$ \\
\hline $\mathrm{Co}$ & & $1.11431 \mathrm{E}-04$ & $7.83050 \mathrm{E}-05$ \\
\hline $\mathrm{Fe}$ & & $6.15902 \mathrm{E}-02$ & $5.86255 \mathrm{E}-02$ \\
\hline $\mathrm{N}$ & & & $2.71726 \mathrm{E}-04$ \\
\hline $\mathrm{H}$ & $6.68559 \mathrm{E}-02$ & & \\
\hline $\mathrm{O}$ & $3.34279 \mathrm{E}-02$ & & \\
\hline
\end{tabular}

ORNL 2000-1342C EFG

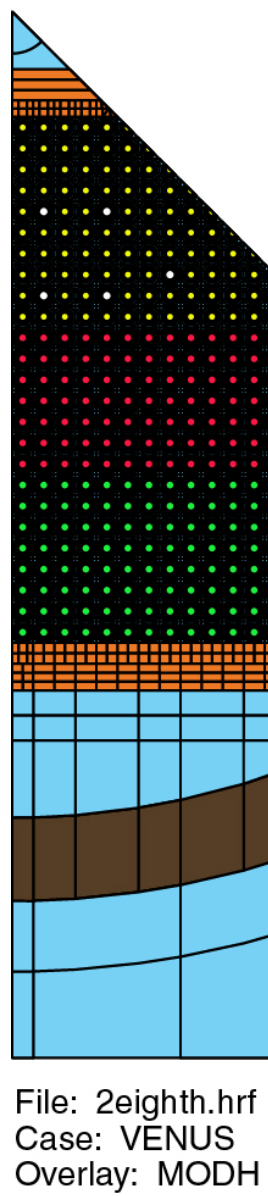

Materials

baf

barrel

clad33

clad402027

cladpyrex

$\square \mathrm{cool}$

$\square$ fuel2027

$\square$ fuel33

fuel40

pyrex

$\square$ void

Overlay: $\mathrm{MODH}$

Fig. 5. ORNL HELIOS code model for VENUS-2. 


\section{RESULTS}

\subsection{CELL CALCULATIONS}

For comparison of the trends related to the number of neutron-energy groups, cell calculations were performed with the 34-, 89-, and 190-neutron-energy group libraries for all three fuel cell types. The complete results are presented in Table 5 for the $\mathrm{k}_{\text {inf }}$ calculations, as well as for $\mathrm{k}_{\text {eff }}$ and $\mathrm{k}_{\mathrm{o}}$ calculations for a buckling of $2.4 \times 10^{-3} \mathrm{~cm}^{-2}$. The $\mathrm{k}_{\mathrm{eff}}$ and $\mathrm{k}_{\mathrm{o}}$ calculations are shown here for illustrative purposes only because the assumed buckling is not necessarily applicable to infinite arrays of these fuel pin cells. The $\mathrm{k}_{\mathrm{o}}$ multiplication factor is the $\mathrm{k}_{\text {inf }}$ but as calculated in the neutron spectrum corresponding to the input buckling.

Table 5. Cell $k$ determinations as a function of the number of neutron energy groups

\begin{tabular}{lcccc}
\hline Fuel & $\begin{array}{c}\text { Number of } \\
\text { neutron- } \\
\text { energy groups }\end{array}$ & $\mathbf{k}_{\text {inf }}$ & $\mathbf{k}_{\text {eff }}$ & $\mathbf{k}_{\mathbf{o}}$ \\
\hline $3.3 \mathrm{wt} \%$ & 190 & 1.40847 & 1.28867 & 1.40608 \\
& 89 & 1.40677 & 1.28739 & 1.40441 \\
$4.0 \mathrm{wt} \%$ & 34 & 1.40698 & 1.28834 & 1.40478 \\
& 190 & 1.34333 & 1.23504 & 1.34161 \\
$2.0 / 2.7 \mathrm{wt} \%$ & 89 & 1.34152 & 1.23366 & 1.33983 \\
& 34 & 1.34130 & 1.23391 & 1.33977 \\
& 190 & 1.26254 & 1.15855 & 1.26176 \\
& 89 & 1.26279 & 1.15905 & 1.26204 \\
& 34 & 1.26496 & 1.16176 & 1.26435 \\
\hline
\end{tabular}

In 3.3 and $4.0 \mathrm{wt} \%$ fuel, for example, 89- and 34-group results for $\mathrm{k}_{\mathrm{inf}}$ are similar, and the 190-group result is somewhat higher; for 2.0/2.7 wt \% MOX, 190-group and 89-group $\mathrm{k}_{\text {inf }}$ are similar, and $34 \mathrm{G}_{\text {inf }}$ is somewhat higher. Similar trends exist for $\mathrm{k}_{\mathrm{o}}$. Trends in $\mathrm{k}_{\mathrm{eff}}$ are also different between MOX and LEU pin cells. Overall, the differences in MOX k behavior are probably a result of "plutonium effects" and group-dependent reaction rates.

The 190-group $\mathrm{k}_{\mathrm{inf}}$ values from ORNL using HELIOS-1.4 were presented to OECD/NEA as the benchmark results. These are isolated in Table 6.

Table 6. The 190-group $k_{\text {inf }}$ values

\begin{tabular}{lc}
\hline \multicolumn{1}{c}{ Fuel cell } & $\mathbf{k}_{\text {inf }}$ \\
\hline $3.3 \mathrm{wt} \% \mathrm{UO}_{2}$ & 1.40847 \\
$4.0 \mathrm{wt} \% \mathrm{UO}_{2}$ & 1.34333 \\
$2.0 / 2.7 \mathrm{wt} \% \mathrm{MOX}$ & 1.26254 \\
\hline
\end{tabular}

Table 7 shows the results for the cell calculations from all of the benchmark participants. These data are from the OECD/NEA final report. ${ }^{2}$ 
Table 7. The $\mathbf{k}_{\text {inf }}$ values of cell calculations

\begin{tabular}{|c|c|c|c|c|c|}
\hline Institution & Method & Basic library & $\mathrm{UO}_{2} 3.3 \mathrm{wt} \%$ & $\mathrm{UO}_{2} 4.0 \mathrm{wt} \%$ & MOX \\
\hline NEA & SCALE-4.4 (44g) & ENDF/B-V & 1.40385 & 1.33366 & 1.25345 \\
\hline KAERI & $\begin{array}{l}\text { HELIOS-1.5 } \\
(35 \mathrm{~g})\end{array}$ & ENDF/B-VI & 1.40904 & 1.34306 & 1.26339 \\
\hline ORNL & $\begin{array}{l}\text { HELIOS-1.4 } \\
(190 \mathrm{~g})\end{array}$ & ENDF/B-VI & 1.40847 & 1.34333 & 1.26254 \\
\hline PSI & BOXER & JEF-1 & 1.39636 & 1.33226 & 1.26179 \\
\hline SCK-CEN & $\begin{array}{l}\text { SCALE-4.4 } \\
(238 \mathrm{~g})\end{array}$ & ENDF/B-V & 1.39917 & 1.32829 & 1.24894 \\
\hline \multirow[t]{2}{*}{ IJS-Trkov } & WIMS-D (69g) & JEF-2.2 & 1.40358 & 1.33298 & 1.24858 \\
\hline & WIMS-D (69g) & ENDF/B-VI & 1.39840 & 1.32760 & 1.24730 \\
\hline NEA+KAERI & MCNP-4B & ENDF/B-VI & $\begin{array}{c}1.40479 \\
( \pm 0.00053)\end{array}$ & $\begin{array}{c}1.33635 \\
( \pm 0.00056)\end{array}$ & $\begin{array}{c}1.25447 \\
( \pm 0.00061)\end{array}$ \\
\hline JAERI & MVP & JENDL-3.2 & $\begin{array}{c}1.41115 \\
( \pm 0.00044)\end{array}$ & $\begin{array}{c}1.34549 \\
( \pm 0.00043)\end{array}$ & $\begin{array}{c}1.26313 \\
( \pm 0.00051)\end{array}$ \\
\hline $\begin{array}{l}\text { Kurchatov } \\
\text { Institute }\end{array}$ & MCU-B & $\begin{array}{l}\text { ENDF/B-VI } \\
\text { JENDL-3.2 } \\
\text { BROND }\end{array}$ & 1.40710 & 1.33650 & 1.25490 \\
\hline KFKI & MCNP-4B & ENDF/B-VI & $\begin{array}{c}1.40650 \\
( \pm 0.00086)\end{array}$ & $\begin{array}{c}1.33640 \\
( \pm 0.00088)\end{array}$ & $\begin{array}{l}1.26310 \\
( \pm 0.001)\end{array}$ \\
\hline \multirow[t]{2}{*}{ GRS } & $\begin{array}{l}\text { MCNP-4B } \\
\text { (square cell) }\end{array}$ & JEF-2.2 & $\begin{array}{c}1.41120 \\
( \pm 0.0004)\end{array}$ & $\begin{array}{c}1.34370 \\
( \pm 0.0004)\end{array}$ & $\begin{array}{l}1.26140 \\
( \pm 0.0004)\end{array}$ \\
\hline & $\begin{array}{l}\text { MCNP-4B } \\
\text { (cylindrical cell) }\end{array}$ & JEF-2.2 & $\begin{array}{c}1.40950 \\
( \pm 0.0004)\end{array}$ & $\begin{array}{c}1.34020 \\
( \pm 0.0004)\end{array}$ & $\begin{array}{l}1.25430 \\
( \pm 0.0004)\end{array}$ \\
\hline IJS-Jeraj & MCNP-4B & ENDF/B-VI & $\begin{array}{l}1.40480 \\
( \pm 0.0002)\end{array}$ & $\begin{array}{c}1.33610 \\
( \pm 0.0002)\end{array}$ & $\begin{array}{l}1.25470 \\
( \pm 0.0002)\end{array}$ \\
\hline
\end{tabular}

The following Tables 8-31 present fission and absorption rates by specified nuclides for the three fuel pin-cell models for each of the three assigned neutron energy ranges, and the integrated rates over all energies. The OECD/NEA benchmark coordinator will normalize these tabulated rates such that the total fission rate per cell will be 1 fission/s, as presented in Ref. 2.

The first set of tables (Tables 8-19) is for cell calculations with neutron leakage approximated by an axial buckling of $2.4 \times 10^{-3} \mathrm{~cm}^{-2}$. The second set of tables (Tables 20-31) represents the reaction rates for true infinite cell calculations, with no buckling.

Table 8. Energy integrated reaction rates in 2.0/2.7 wt \% $\operatorname{MOX}\left(\right.$ reactions $\left./ \mathrm{cm}^{3} / \mathrm{s}\right)\left(\mathrm{B}^{2}=2.4 \times 10^{-3} \mathrm{~cm}^{-2}\right)$

\begin{tabular}{lcc}
\hline & Absorption & Fission \\
\hline${ }^{234} \mathrm{U}$ & $3.6570 \mathrm{E}+05$ & $1.0154 \mathrm{E}+04$ \\
${ }^{235} \mathrm{U}$ & $7.1403 \mathrm{E}+07$ & $5.6392 \mathrm{E}+07$ \\
${ }^{236} \mathrm{U}$ & $1.3013 \mathrm{E}+05$ & $4.9229 \mathrm{E}+03$ \\
${ }^{238} \mathrm{U}$ & $9.5451 \mathrm{E}+07$ & $1.2245 \mathrm{E}+07$ \\
${ }^{239} \mathrm{Pu}$ & $1.7165 \mathrm{E}+08$ & $1.1283 \mathrm{E}+08$ \\
${ }^{240} \mathrm{Pu}$ & $3.4993 \mathrm{E}+07$ & $3.2684 \mathrm{E}+05$ \\
${ }^{241} \mathrm{Pu}$ & $6.9046 \mathrm{E}+06$ & $5.1946 \mathrm{E}+06$ \\
${ }^{242} \mathrm{Pu}$ & $4.5645 \mathrm{E}+05$ & $6.3531 \mathrm{E}+03$ \\
${ }^{241} \mathrm{Am}$ & $1.4801 \mathrm{E}+05$ & $2.1193 \mathrm{E}+03$ \\
\hline
\end{tabular}


Table 9. Energy integrated reaction rates in $3.3 \mathrm{wt} \% \mathrm{UO}_{2}\left(\right.$ reactions $\left./ \mathrm{cm}^{3} / \mathrm{s}\right)\left(\mathrm{B}^{2}=2.4 \times 10^{-3} \mathrm{~cm}^{-2}\right)$

\begin{tabular}{ccc}
\hline & Absorption & Fission \\
\hline${ }^{234} \mathrm{U}$ & $6.7993 \mathrm{E}+05$ & $1.4198 \mathrm{E}+04$ \\
${ }^{235} \mathrm{U}$ & $2.1540 \mathrm{E}+08$ & $1.7821 \mathrm{E}+08$ \\
${ }^{236} \mathrm{U}$ & $1.2843 \mathrm{E}+05$ & $4.5400 \mathrm{E}+03$ \\
${ }^{238} \mathrm{U}$ & $8.6857 \mathrm{E}+07$ & $8.7645 \mathrm{E}+06$ \\
\hline
\end{tabular}

Table 10. Energy integrated reaction rates in 4.0 wt $\% \mathrm{UO}_{2}\left(\right.$ reactions $\left./ \mathrm{cm}^{3} / \mathrm{s}\right)\left(\mathrm{B}^{2}=2.4 \times 10^{-3} \mathrm{~cm}^{-2}\right)$

\begin{tabular}{ccc}
\hline & Absorption & Fission \\
\hline${ }^{234} \mathrm{U}$ & $7.4626 \mathrm{E}+05$ & $1.8069 \mathrm{E}+04$ \\
${ }^{235} \mathrm{U}$ & $2.1634 \mathrm{E}+08$ & $1.7646 \mathrm{E}+08$ \\
${ }^{236} \mathrm{U}$ & $2.1199 \mathrm{E}+05$ & $7.7924 \mathrm{E}+03$ \\
${ }^{238} \mathrm{U}$ & $9.2756 \mathrm{E}+07$ & $1.0498 \mathrm{E}+07$ \\
\hline
\end{tabular}

Table 11. Group $1(\mathrm{E}>5 \mathrm{kV})$ reaction rates in 2.0/2.7 wt \% MOX (reactions $/ \mathrm{cm}^{3} / \mathrm{s}$ ) $\left(B^{2}=2.4 \times 10^{-3} \mathrm{~cm}^{-2}\right)$

\begin{tabular}{ccc}
\hline & Absorption & Fission \\
\hline${ }^{234} \mathrm{U}$ & $1.3612 \mathrm{E}+04$ & $9.6131 \mathrm{E}+03$ \\
${ }^{235} \mathrm{U}$ & $2.5835 \mathrm{E}+06$ & $2.1935 \mathrm{E}+06$ \\
${ }^{236} \mathrm{U}$ & $5.4583 \mathrm{E}+03$ & $3.2783 \mathrm{E}+03$ \\
${ }^{238} \mathrm{U}$ & $2.3452 \mathrm{E}+07$ & $1.2245 \mathrm{E}+07$ \\
${ }^{239} \mathrm{Pu}$ & $3.1350 \mathrm{E}+06$ & $2.8058 \mathrm{E}+06$ \\
${ }^{240} \mathrm{Pu}$ & $3.9708 \mathrm{E}+05$ & $3.0783 \mathrm{E}+05$ \\
${ }^{241} \mathrm{Pu}$ & $1.3127 \mathrm{E}+05$ & $1.1925 \mathrm{E}+05$ \\
${ }^{242} \mathrm{Pu}$ & $8.2533 \mathrm{E}+03$ & $6.2709 \mathrm{E}+03$ \\
${ }^{241} \mathrm{Am}$ & $2.7516 \mathrm{E}+03$ & $1.2800 \mathrm{E}+03$ \\
\hline
\end{tabular}

Table 12. Group $1(\mathrm{E}>5 \mathrm{kV})$ reaction rates in $3.3 \mathrm{wt} \% \mathrm{UO}_{2}\left(\right.$ reactions $\left./ \mathrm{cm}^{3} / \mathrm{s}\right)\left(\mathrm{B}^{2}=2.4 \times 10^{-3} \mathrm{~cm}^{-2}\right)$

\begin{tabular}{ccc}
\hline & Absorption & Fission \\
\hline${ }^{234} \mathrm{U}$ & $1.7969 \mathrm{E}+04$ & $1.2703 \mathrm{E}+04$ \\
${ }^{235} \mathrm{U}$ & $3.0985 \mathrm{E}+06$ & $2.6312 \mathrm{E}+06$ \\
${ }^{236} \mathrm{U}$ & $4.8836 \mathrm{E}+03$ & $2.9350 \mathrm{E}+03$ \\
${ }^{238} \mathrm{U}$ & $1.6814 \mathrm{E}+07$ & $8.7644 \mathrm{E}+06$ \\
\hline
\end{tabular}


Table 13. Group $1(E>5 \mathrm{kV})$ reaction rates in $4.0 \mathrm{wt} \% \mathrm{UO}_{2}$ (reactions $\left./ \mathrm{cm}^{3} / \mathrm{s}\right)\left(\mathrm{B}^{2}=2.4 \times 10^{-3} \mathrm{~cm}^{-2}\right)$

\begin{tabular}{ccc}
\hline & Absorption & Fission \\
\hline${ }^{234} \mathrm{U}$ & $2.3798 \mathrm{E}+04$ & $1.6665 \mathrm{E}+04$ \\
${ }^{235} \mathrm{U}$ & $4.7405 \mathrm{E}+06$ & $4.0160 \mathrm{E}+06$ \\
${ }^{236} \mathrm{U}$ & $8.6837 \mathrm{E}+03$ & $5.1211 \mathrm{E}+03$ \\
${ }^{238} \mathrm{U}$ & $2.0658 \mathrm{E}+07$ & $1.0498 \mathrm{E}+07$ \\
\hline
\end{tabular}

Table 14. Group $2(4 \mathrm{eV}<\mathrm{E}<5 \mathrm{kV})$ reaction rates in 2.0/2.7 wt \% MOX $\left(\right.$ reactions $\left./ \mathrm{cm}^{3} / \mathrm{s}\right)\left(\mathrm{B}^{2}=2.4 \times 10^{-3} \mathrm{~cm}^{-2}\right)$

\begin{tabular}{lcc}
\hline & Absorption & Fission \\
\hline${ }^{234} \mathrm{U}$ & $2.8787 \mathrm{E}+05$ & $2.6684 \mathrm{E}+02$ \\
${ }^{235} \mathrm{U}$ & $1.8295 \mathrm{E}+07$ & $1.1320 \mathrm{E}+07$ \\
${ }^{236} \mathrm{U}$ & $1.2134 \mathrm{E}+05$ & $1.6127 \mathrm{E}+03$ \\
${ }^{238} \mathrm{U}$ & $5.9883 \mathrm{E}+07$ & $0.0000 \mathrm{E}+01$ \\
${ }^{239} \mathrm{Pu}$ & $2.1946 \mathrm{E}+07$ & $1.2758 \mathrm{E}+07$ \\
${ }^{240} \mathrm{Pu}$ & $1.8693 \mathrm{E}+06$ & $1.2437 \mathrm{E}+04$ \\
${ }^{241} \mathrm{Pu}$ & $1.5360 \mathrm{E}+06$ & $1.1653 \mathrm{E}+06$ \\
${ }^{242} \mathrm{Pu}$ & $2.0463 \mathrm{E}+04$ & $8.1635 \mathrm{E}+01$ \\
${ }^{241} \mathrm{Am}$ & $1.9874 \mathrm{E}+04$ & $1.5607 \mathrm{E}+02$ \\
\hline
\end{tabular}

Table 15. Group $2(4 \mathrm{eV}<\mathrm{E}<5 \mathrm{kV})$ reaction rates in $3.3 \mathrm{wt} \% \mathrm{UO}_{2}$ $\left(\right.$ reactions $\left./ \mathrm{cm}^{3} / \mathrm{s}\right)\left(\mathrm{B}^{2}=2.4 \times 10^{-3} \mathrm{~cm}^{-2}\right)$

\begin{tabular}{lcc}
\hline & Absorption & Fission \\
\hline${ }^{234} \mathrm{U}$ & $4.0409 \mathrm{E}+05$ & $3.6413 \mathrm{E}+02$ \\
${ }^{235} \mathrm{U}$ & $2.2526 \mathrm{E}+07$ & $1.3908 \mathrm{E}+07$ \\
${ }^{236} \mathrm{U}$ & $1.1552 \mathrm{E}+05$ & $1.5302 \mathrm{E}+03$ \\
${ }^{238} \mathrm{U}$ & $4.5539 \mathrm{E}+07$ & $0.0000 \mathrm{E}+01$ \\
\hline
\end{tabular}

Table 16. Group $2(4 \mathrm{eV}<\mathrm{E}<5 \mathrm{kV})$ reaction rates in $4.0 \mathrm{wt} \% \mathrm{UO}_{2}$ $\left(\right.$ reactions $\left./ \mathrm{cm}^{3} / \mathrm{s}\right)\left(\mathrm{B}^{2}=2.4 \times 10^{-3} \mathrm{~cm}^{-2}\right)$

\begin{tabular}{lcc}
\hline & Absorption & Fission \\
\hline${ }^{234} \mathrm{U}$ & $5.0819 \mathrm{E}+05$ & $4.7356 \mathrm{E}+02$ \\
${ }^{235} \mathrm{U}$ & $3.2688 \mathrm{E}+07$ & $2.0294 \mathrm{E}+07$ \\
${ }^{236} \mathrm{U}$ & $1.9389 \mathrm{E}+05$ & $2.5827 \mathrm{E}+03$ \\
${ }^{238} \mathrm{U}$ & $5.2529 \mathrm{E}+07$ & $0.0000 \mathrm{E}+01$ \\
\hline
\end{tabular}




\begin{tabular}{|c|c|c|}
\hline & Absorption & Fission \\
\hline & $6.4221 \mathrm{E}+04$ & $2.7382 \mathrm{E}+02$ \\
\hline $\mathrm{U}$ & $5.0525 \mathrm{E}+07$ & $4.2878 \mathrm{E}+07$ \\
\hline $\mathrm{U}$ & $3.3276 \mathrm{E}+03$ & $3.1874 \mathrm{E}+01$ \\
\hline & $1.2115 \mathrm{E}+07$ & $4.7288 \mathrm{E}+01$ \\
\hline $\mathrm{Pu}$ & $1.4657 \mathrm{E}+08$ & $9.7269 \mathrm{E}+07$ \\
\hline${ }^{40} \mathrm{Pu}$ & $3.2727 \mathrm{E}+07$ & $6.5701 \mathrm{E}+03$ \\
\hline${ }^{41} \mathrm{Pu}$ & $5.2373 \mathrm{E}+06$ & $3.9101 \mathrm{E}+06$ \\
\hline${ }^{242} \mathrm{Pu}$ & $4.2773 \mathrm{E}+05$ & 5.3384E-01 \\
\hline${ }^{241} \mathrm{Am}$ & $1.2538 \mathrm{E}+05$ & $6.8328 \mathrm{E}+02$ \\
\hline
\end{tabular}

Table 18. Group $3(\mathrm{E}<4 \mathrm{eV})$ reaction rates in $3.3 \mathrm{wt} \% \mathrm{UO}_{2}$ (reactions $/ \mathrm{cm}^{3} / \mathrm{s}$ ) $\left(B^{2}=2.4 \times 10^{-3} \mathrm{~cm}^{-2}\right)$

\begin{tabular}{lcc}
\hline & Absorption & Fission \\
\hline${ }^{234} \mathrm{U}$ & $2.5787 \mathrm{E}+05$ & $1.1305 \mathrm{E}+03$ \\
${ }^{235} \mathrm{U}$ & $1.8978 \mathrm{E}+08$ & $1.6167 \mathrm{E}+08$ \\
${ }^{236} \mathrm{U}$ & $8.0263 \mathrm{E}+03$ & $7.4869 \mathrm{E}+01$ \\
${ }^{238} \mathrm{U}$ & $2.4504 \mathrm{E}+07$ & $1.0184 \mathrm{E}+02$ \\
\hline
\end{tabular}

Table 19. Group $3(\mathrm{E}<4 \mathrm{eV})$ reaction rates in $4.0 \mathrm{wt} \% \mathrm{UO}_{2}$ (reactions $/ \mathrm{cm}^{3} / \mathrm{s}$ ) $\left(B^{2}=2.4 \times 10^{-3} \mathrm{~cm}^{-2}\right)$

\begin{tabular}{lcc}
\hline & Absorption & Fission \\
\hline${ }^{234} \mathrm{U}$ & $2.1427 \mathrm{E}+05$ & $9.3016 \mathrm{E}+02$ \\
${ }^{235} \mathrm{U}$ & $1.7891 \mathrm{E}+08$ & $1.5215 \mathrm{E}+08$ \\
${ }^{236} \mathrm{U}$ & $9.4139 \mathrm{E}+03$ & $8.8667 \mathrm{E}+01$ \\
${ }^{238} \mathrm{U}$ & $1.9569 \mathrm{E}+07$ & $7.9796 \mathrm{E}+01$ \\
\hline
\end{tabular}

The following tables (Tables 20-31) are for cell calculations with no buckling and represent the infinite pin-cell calculations. Tables $8-19$, as discussed previously, present reaction rate results for the cases with nominal bucklings $\left(2.4 \times 10^{-3} \mathrm{~cm}^{-2}\right)$. The results shown in the following infinite cell calculation data are slightly different from those for the corresponding buckled calculations presented previously. 
Table 20. Energy integrated reaction rates in 2.0/2.7 wt \% MOX (reactions $\left./ \mathrm{cm}^{3} / \mathrm{s}\right)\left(B^{2}=0\right)$

\begin{tabular}{lcc}
\hline & Absorption & Fission \\
\hline${ }^{234} \mathrm{U}$ & $3.6514 \mathrm{E}+05$ & $9.8900 \mathrm{E}+03$ \\
${ }^{235} \mathrm{U}$ & $7.1473 \mathrm{E}+07$ & $5.6467 \mathrm{E}+07$ \\
${ }^{236} \mathrm{U}$ & $1.2978 \mathrm{E}+05$ & $4.8305 \mathrm{E}+03$ \\
${ }^{238} \mathrm{U}$ & $9.4669 \mathrm{E}+07$ & $1.1924 \mathrm{E}+07$ \\
${ }^{239} \mathrm{Pu}$ & $1.7204 \mathrm{E}+08$ & $1.1308 \mathrm{E}+08$ \\
${ }^{240} \mathrm{Pu}$ & $3.5042 \mathrm{E}+07$ & $3.1834 \mathrm{E}+05$ \\
${ }^{241} \mathrm{Pu}$ & $6.9183 \mathrm{E}+06$ & $5.2042 \mathrm{E}+06$ \\
${ }^{242} \mathrm{Pu}$ & $4.5649 \mathrm{E}+05$ & $6.1785 \mathrm{E}+03$ \\
${ }^{241} \mathrm{Am}$ & $1.4827 \mathrm{E}+05$ & $2.0857 \mathrm{E}+03$ \\
\hline
\end{tabular}

Table 21. Energy integrated reaction rates in $3.3 \mathrm{wt} \% \mathrm{UO}_{2}\left(\right.$ reactions $\left./ \mathrm{cm}^{3} / \mathrm{s}\right)\left(\mathrm{B}^{2}=0\right)$

\begin{tabular}{lcc}
\hline & Absorption & Fission \\
\hline${ }^{234} \mathrm{U}$ & $6.7755 \mathrm{E}+05$ & $1.3808 \mathrm{E}+04$ \\
${ }^{235} \mathrm{U}$ & $2.1565 \mathrm{E}+08$ & $1.7848 \mathrm{E}+08$ \\
${ }^{236} \mathrm{U}$ & $1.2754 \mathrm{E}+05$ & $4.4421 \mathrm{E}+03$ \\
${ }^{238} \mathrm{U}$ & $8.6030 \mathrm{E}+07$ & $8.5145 \mathrm{E}+06$ \\
\hline
\end{tabular}

Table 22. Energy integrated reaction rates in 4.0 wt $\% \mathrm{UO}_{2}\left(\right.$ reactions $\left./ \mathrm{cm}^{3} / \mathrm{s}\right)\left(\mathrm{B}^{2}=0\right)$

\begin{tabular}{lcc}
\hline & Absorption & Fission \\
\hline${ }^{234} \mathrm{U}$ & $7.4428 \mathrm{E}+05$ & $1.7585 \mathrm{E}+04$ \\
${ }^{235} \mathrm{U}$ & $2.1664 \mathrm{E}+08$ & $1.7676 \mathrm{E}+08$ \\
${ }^{236} \mathrm{U}$ & $2.1095 \mathrm{E}+05$ & $7.6339 \mathrm{E}+03$ \\
${ }^{238} \mathrm{U}$ & $9.1931 \mathrm{E}+07$ & $1.0206 \mathrm{E}+07$ \\
\hline
\end{tabular}

Table 23. Group $1(\mathrm{E}>5 \mathrm{kV})$ reaction rates in 2.0/2.7 wt \% MOX $\left(\right.$ reactions $\left./ \mathrm{cm}^{3} / \mathrm{s}\right)\left(\mathrm{B}^{2}=\mathbf{0}\right)$

\begin{tabular}{lcc}
\hline & Absorption & Fission \\
\hline${ }^{234} \mathrm{U}$ & $1.3265 \mathrm{E}+04$ & $9.3495 \mathrm{E}+03$ \\
${ }^{235} \mathrm{U}$ & $2.5268 \mathrm{E}+06$ & $2.1442 \mathrm{E}+06$ \\
${ }^{236} \mathrm{U}$ & $5.3268 \mathrm{E}+03$ & $3.1895 \mathrm{E}+03$ \\
${ }^{238} \mathrm{U}$ & $2.2907 \mathrm{E}+07$ & $1.1924 \mathrm{E}+07$ \\
${ }^{239} \mathrm{Pu}$ & $3.0616 \mathrm{E}+06$ & $2.7380 \mathrm{E}+06$ \\
${ }^{240} \mathrm{Pu}$ & $3.8704 \mathrm{E}+05$ & $2.9942 \mathrm{E}+05$ \\
${ }^{241} \mathrm{Pu}$ & $1.2834 \mathrm{E}+05$ & $1.1656 \mathrm{E}+05$ \\
${ }^{242} \mathrm{Pu}$ & $8.0427 \mathrm{E}+03$ & $6.0970 \mathrm{E}+03$ \\
${ }^{241} \mathrm{Am}$ & $2.6878 \mathrm{E}+03$ & $1.2447 \mathrm{E}+03$ \\
\hline
\end{tabular}


Table 24. Group $1(\mathrm{E}>5 \mathrm{kV})$ reaction rates in $3.3 \mathrm{wt} \% \mathrm{UO}_{2}\left(\right.$ reactions $\left./ \mathrm{cm}^{3} / \mathrm{s}\right)\left(\mathrm{B}^{2}=0\right)$

\begin{tabular}{lcc}
\hline & Absorption & Fission \\
\hline${ }^{234} \mathrm{U}$ & $1.7445 \mathrm{E}+04$ & $1.2314 \mathrm{E}+04$ \\
${ }^{235} \mathrm{U}$ & $3.0167 \mathrm{E}+06$ & $2.5607 \mathrm{E}+06$ \\
${ }^{236} \mathrm{U}$ & $4.7482 \mathrm{E}+03$ & $2.8477 \mathrm{E}+03$ \\
${ }^{238} \mathrm{U}$ & $1.6360 \mathrm{E}+07$ & $8.5144 \mathrm{E}+06$ \\
\hline
\end{tabular}

Table 25. Group $1(\mathrm{E}>5 \mathrm{kV})$ reaction rates in $4.0 \mathrm{wt} \% \mathrm{UO}_{2}\left(\right.$ reactions $\left./ \mathrm{cm}^{3} / \mathrm{s}\right)\left(\mathrm{B}^{2}=0\right)$

\begin{tabular}{lcc}
\hline & Absorption & Fission \\
\hline${ }^{234} \mathrm{U}$ & $2.3153 \mathrm{E}+04$ & $1.6182 \mathrm{E}+04$ \\
${ }^{235} \mathrm{U}$ & $4.6277 \mathrm{E}+06$ & $3.9186 \mathrm{E}+06$ \\
${ }^{236} \mathrm{U}$ & $8.4602 \mathrm{E}+03$ & $4.9745 \mathrm{E}+03$ \\
${ }^{238} \mathrm{U}$ & $2.0144 \mathrm{E}+07$ & $1.0206 \mathrm{E}+07$ \\
\hline
\end{tabular}

Table 26. Group $2(4 \mathrm{eV}<\mathrm{E}<5 \mathrm{kV})$ reaction rates in 2.0/2.7 wt \% MOX $\left(\right.$ reactions $\left./ \mathrm{cm}^{3} / \mathrm{s}\right)\left(\mathrm{B}^{2}=\mathbf{0}\right)$

\begin{tabular}{lcc}
\hline & Absorption & Fission \\
\hline${ }^{234} \mathrm{U}$ & $2.8739 \mathrm{E}+05$ & $2.6550 \mathrm{E}+02$ \\
${ }^{235} \mathrm{U}$ & $1.8214 \mathrm{E}+07$ & $1.1267 \mathrm{E}+07$ \\
${ }^{236} \mathrm{U}$ & $1.2111 \mathrm{E}+05$ & $1.6090 \mathrm{E}+03$ \\
${ }^{238} \mathrm{U}$ & $5.9602 \mathrm{E}+07$ & $0.0000 \mathrm{E}+00$ \\
${ }^{239} \mathrm{Pu}$ & $2.1852 \mathrm{E}+07$ & $1.2704 \mathrm{E}+07$ \\
${ }^{240} \mathrm{Pu}$ & $1.8596 \mathrm{E}+06$ & $1.2333 \mathrm{E}+04$ \\
${ }^{241} \mathrm{Pu}$ & $1.5315 \mathrm{E}+06$ & $1.1617 \mathrm{E}+06$ \\
${ }^{242} \mathrm{Pu}$ & $2.0348 \mathrm{E}+04$ & $8.1035 \mathrm{E}+01$ \\
${ }^{241} \mathrm{Am}$ & $1.9799 \mathrm{E}+04$ & $1.5555 \mathrm{E}+02$ \\
\hline
\end{tabular}

Table 27. Group $2(4 \mathrm{eV}<\mathrm{E}<5 \mathrm{kV})$ reaction rates in $3.3 \mathrm{wt} \% \mathrm{UO}_{2}$ $\left(\right.$ reactions $\left./ \mathrm{cm}^{3} / \mathrm{s}\right)\left(\mathrm{B}^{2}=\mathbf{0}\right)$

\begin{tabular}{lcc}
\hline & Absorption & Fission \\
\hline${ }^{234} \mathrm{U}$ & $4.0150 \mathrm{E}+05$ & $3.6054 \mathrm{E}+02$ \\
${ }^{235} \mathrm{U}$ & $2.2316 \mathrm{E}+07$ & $1.3775 \mathrm{E}+07$ \\
${ }^{236} \mathrm{U}$ & $1.1475 \mathrm{E}+05$ & $1.5194 \mathrm{E}+03$ \\
${ }^{238} \mathrm{U}$ & $4.5104 \mathrm{E}+07$ & $0.0000 \mathrm{E}+00$ \\
\hline
\end{tabular}


Table 28. Group $2(4 \mathrm{eV}<\mathrm{E}<5 \mathrm{kV})$ reaction rates in $4.0 \mathrm{wt} \% \mathrm{UO}_{2}$ $\left(\right.$ reactions $\left./ \mathrm{cm}^{3} / \mathrm{s}\right)\left(\mathrm{B}^{2}=\mathbf{0}\right)$

\begin{tabular}{lcc}
\hline & Absorption & Fission \\
\hline${ }^{234} \mathrm{U}$ & $5.0609 \mathrm{E}+05$ & $4.7005 \mathrm{E}+02$ \\
${ }^{235} \mathrm{U}$ & $3.2462 \mathrm{E}+07$ & $2.0149 \mathrm{E}+07$ \\
${ }^{236} \mathrm{U}$ & $1.9304 \mathrm{E}+05$ & $2.5704 \mathrm{E}+03$ \\
${ }^{238} \mathrm{U}$ & $5.2156 \mathrm{E}+07$ & $0.0000 \mathrm{E}+00$ \\
\hline
\end{tabular}

Table 29. Group $3(\mathrm{E}<4 \mathrm{eV})$ reaction rates in 2.0/2.7 wt \% MOX $\left(\right.$ reactions $\left./ \mathrm{cm}^{3} / \mathrm{s}\right)\left(\mathrm{B}^{2}=\mathbf{0}\right)$

\begin{tabular}{lcc}
\hline & Absorption & Fission \\
\hline${ }^{234} \mathrm{U}$ & $6.4480 \mathrm{E}+04$ & $2.7496 \mathrm{E}+02$ \\
${ }^{235} \mathrm{U}$ & $5.0732 \mathrm{E}+07$ & $4.3056 \mathrm{E}+07$ \\
${ }^{236} \mathrm{U}$ & $3.3393 \mathrm{E}+03$ & $3.1982 \mathrm{E}+01$ \\
${ }^{238} \mathrm{U}$ & $1.2161 \mathrm{E}+07$ & $4.7480 \mathrm{E}+01$ \\
${ }^{239} \mathrm{Pu}$ & $1.4713 \mathrm{E}+08$ & $9.7641 \mathrm{E}+07$ \\
${ }^{240} \mathrm{Pu}$ & $3.2795 \mathrm{E}+07$ & $6.5840 \mathrm{E}+03$ \\
${ }^{241} \mathrm{Pu}$ & $5.2585 \mathrm{E}+06$ & $3.9259 \mathrm{E}+06$ \\
${ }^{242} \mathrm{Pu}$ & $4.2810 \mathrm{E}+05$ & $5.3591 \mathrm{E}-01$ \\
${ }^{241} \mathrm{Am}$ & $1.2578 \mathrm{E}+05$ & $6.8538 \mathrm{E}+02$ \\
\hline
\end{tabular}

Table 30. Group $3(\mathrm{E}<4 \mathrm{eV})$ reaction rates in $3.3 \mathrm{wt} \% \mathrm{UO}_{2}\left(\right.$ reactions $\left./ \mathrm{cm}^{3} / \mathrm{s}\right)\left(\mathrm{B}^{2}=0\right)$

\begin{tabular}{lcc}
\hline & Absorption & Fission \\
\hline${ }^{234} \mathrm{U}$ & $2.5860 \mathrm{E}+05$ & $1.1338 \mathrm{E}+03$ \\
${ }^{235} \mathrm{U}$ & $1.9032 \mathrm{E}+08$ & $1.6214 \mathrm{E}+08$ \\
${ }^{236} \mathrm{U}$ & $8.0449 \mathrm{E}+03$ & $7.5034 \mathrm{E}+01$ \\
${ }^{238} \mathrm{U}$ & $2.4566 \mathrm{E}+07$ & $1.0212 \mathrm{E}+02$ \\
\hline
\end{tabular}

Table 31. Group $3(\mathrm{E}<4 \mathrm{eV})$ reaction rates in $4.0 \mathrm{wt} \% \mathrm{UO}_{2}\left(\right.$ reactions $\left./ \mathrm{cm}^{3} / \mathrm{s}\right)\left(\mathrm{B}^{2}=0\right)$

\begin{tabular}{lcc}
\hline & Absorption & Fission \\
\hline${ }^{234} \mathrm{U}$ & $2.1503 \mathrm{E}+05$ & $9.3358 \mathrm{E}+02$ \\
${ }^{235} \mathrm{U}$ & $1.7955 \mathrm{E}+08$ & $1.5270 \mathrm{E}+08$ \\
${ }^{236} \mathrm{U}$ & $9.4420 \mathrm{E}+03$ & $8.8921 \mathrm{E}+01$ \\
${ }^{238} \mathrm{U}$ & $1.9632 \mathrm{E}+07$ & $8.0074 \mathrm{E}+01$ \\
\hline
\end{tabular}




\subsection{CORE CALCULATIONS}

The ORNL calculations of $\mathrm{k}_{\text {eff }}$ are presented for the three libraries $(34,89$, and 190 groups) though the definitive value that ORNL reports is the 190-group $\mathrm{k}_{\mathrm{eff}}$ of 0.99870 . Table 32 lists the $\mathrm{k}_{\mathrm{eff}}$ from all the benchmark participants as presented in the OECD/NEA VENUS-2 report. ${ }^{2}$

Table 32. OECD/NEA VENUS-2 core calculation: ORNL VENUS-2 model for HELIOS

\begin{tabular}{|c|c|c|c|}
\hline Institution & Code & $\mathbf{k}_{\text {eff }}$ & Library groups and nuclear data \\
\hline NEA & DORT & 0.99452 & 44G; ENDF/B-V \\
\hline KAERI & HELIOS-1.5 & 0.99817 & 35G; ENDF/B-VI \\
\hline SCK-CEN & DORT & 0.99233 & 44G; ENDF/B-V \\
\hline PSI & BOXER & 1.00378 & $\begin{array}{l}\text { 21G; JEF-1, ENDF/B-IV, BROND-2, } \\
\text { JENDL-2 }\end{array}$ \\
\hline \multirow[t]{2}{*}{ IJS-Trkov } & GNOMER & 0.99450 & 4G; JEF-2.2 \\
\hline & & 0.98977 & 4G; ENDF/B-VI \\
\hline NEA+KAERI & MCNP4B & 1.00213 & Continuous energy; ENDF/B-VI \\
\hline \multirow[t]{3}{*}{ ORNL } & HELIOS-1.4 & 1.00150 & 34G; ENDF/B-VI \\
\hline & & 0.99907 & 89G; ENDF/B-VI \\
\hline & & 0.99870 & 190G; ENDF/B-VI \\
\hline $\mathrm{KI}$ & MCU-B & 0.99650 & $\begin{array}{l}\text { Continuous energy; ENDF/B-VI, } \\
\text { JENDL-3.2, BROND }\end{array}$ \\
\hline KFKI & MCNP-4B & 1.00050 & $\begin{array}{l}\text { Continuous energy; ENDF/B-VI, } \\
\text { ENDF/B-V }\end{array}$ \\
\hline GRS & MCNP-4B & 1.00430 & $\begin{array}{l}\text { Continuous energy; JEF-2.2, ENDF/B- } \\
\text { VI, JENDL-3.1, BROND- } 2.2\end{array}$ \\
\hline IJS-Jeraj & MCNP-4B & 0.99570 & $\begin{array}{l}\text { Continuous energy; ENDF/B-VI, } \\
\text { ENDL85, ENDF/B-III }\end{array}$ \\
\hline
\end{tabular}

Table 33 presents the ORNL results for the pin fission rates normalized to an average of 1 fission/s/pin. The normalized fission rate values in the table were calculated with HELIOS-1.4 with the 190-group library. The ORNL calculational results were submitted to OECD/NEA as part of the blind benchmark before the experimental VENUS-2 results were released.

In Ref. 2, information was presented to allow the determination of calculated-toexperimental (C/E) pin power ratios. At the TFRPD3 meeting in June 2000, it was revealed that experimental pin power values exist for only some of the pin locations, the other pins had interpolated "experimental" powers assigned to them.

The OECD/NEA final VENUS-2 report will discuss comparisons and trends in the C/E distributions from the results of the various participants. They show good agreement of the ORNL results $^{2}$ and in particular, good comparisons to experimental data at the important MOX/LEU and LEU/LEU fuel interfaces.

In Table 34, the ORNL VENUS-2 pin powers are tabulated for a set of representative fuel pins indicated in red lettering in Fig. 4, and the C/E ratios are also shown. Following the delivery of the final ORNL VENUS-2 benchmark results, an improved representation with greater detail was devised for the water between the outer baffle wall and the barrel in the HELIOS VENUS-2 model (as shown in Fig. 5). The calculated pin powers and C/E ratios for the VENUS-2 revised outer model are also presented in Table 34. It is seen that very little changes in most of the pin 
Table 33. Calculated pin power (fission rate) distribution

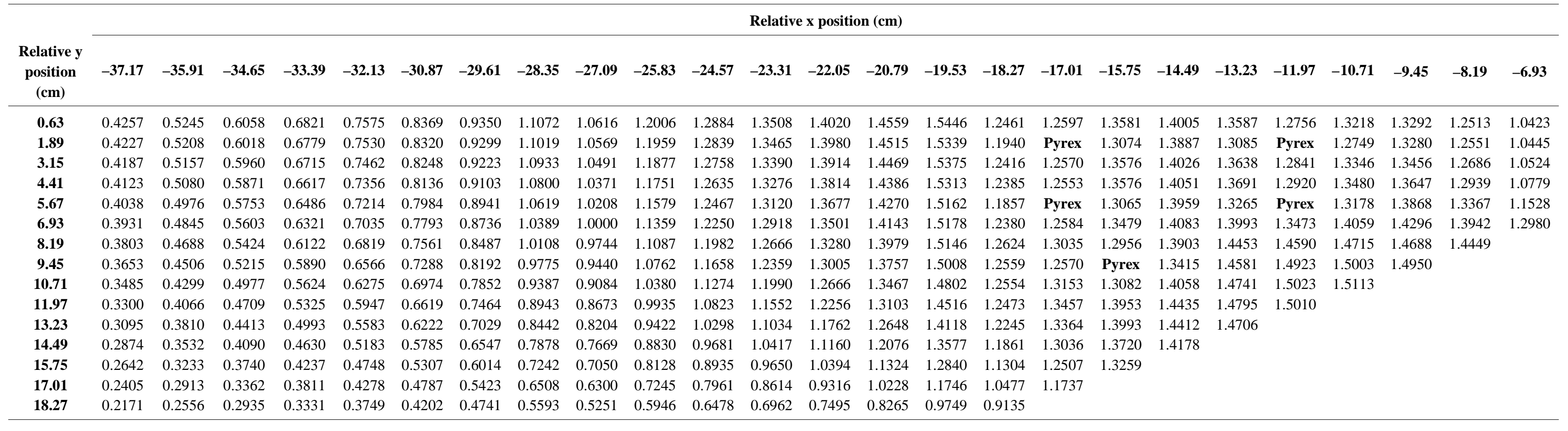


Table 34. ORNL VENUS-2 pin power calculations with HELIOS-1.4 in 190-group: the effect of an improved outer model

\begin{tabular}{cccccc}
\hline $\begin{array}{c}\text { Pin number } \\
\text { (see red- } \\
\text { labeled pins } \\
\text { in Fig. 4) }\end{array}$ & $\begin{array}{c}\text { Reported as part of } \\
\text { the benchmark study }\end{array}$ & & \multicolumn{2}{c}{$\begin{array}{c}\text { Revised outer } \\
\text { model }\end{array}$} \\
\cline { 5 - 6 } \cline { 5 - 6 } Calculated & C/E & & Calculated & C/E \\
\hline 1 & 1.0423 & 0.965 & & 1.0407 & 0.964 \\
5 & 1.1528 & 1.019 & & 1.1511 & 1.018 \\
6 & 1.2980 & 0.996 & & 1.2960 & 0.995 \\
23 & 1.2749 & 0.994 & & 1.2730 & 0.993 \\
34 & 1.3473 & 0.980 & & 1.3454 & 0.980 \\
68 & 1.2956 & 1.007 & & 1.2939 & 1.006 \\
69 & 1.3082 & 0.977 & & 1.3065 & 0.976 \\
85 & 1.1737 & 0.947 & & 1.1724 & 0.946 \\
100 & 0.9135 & 0.986 & & 0.9126 & 0.985 \\
101 & 1.5446 & 0.989 & & 1.5429 & 0.988 \\
229 & 0.7852 & 0.994 & & 0.7856 & 0.995 \\
311 & 0.4257 & 0.983 & & 0.4356 & 1.006 \\
325 & 0.2171 & 0.969 & & 0.2218 & 0.990 \\
\hline
\end{tabular}

powers, except at the periphery by the other baffle wall. The $\mathrm{C} / \mathrm{E}$ ratios for these pins improve considerably.

Table 35 presents the $\mathrm{k}_{\mathrm{eff}}$ values for $190 \mathrm{G}, 89 \mathrm{G}$, and $34 \mathrm{G}$ HELIOS-1.4 VENUS-2 core calculations for this revised ORNL model compared to the previous official model results as presented in Table 32 . The results do not change much ( $\sim 0.03 \%$ reactivity), and the trend to slightly higher $\mathrm{k}_{\mathrm{eff}}$ with fewer groups is the same as earlier noted.

Table 35. ORNL VENUS-2 core $\mathbf{k}_{\text {eff }}$ calculations with HELIOS-1.4: effect of improved outer water model

\begin{tabular}{ccc}
\hline & Reported results & $\begin{array}{c}\text { Using revised } \\
\text { outer model }\end{array}$ \\
\hline $190 \mathrm{G}$ & 0.99870 & 0.99908 \\
$89 \mathrm{G}$ & 0.99907 & 0.99942 \\
$34 \mathrm{G}$ & 1.00150 & 1.00181 \\
\hline
\end{tabular}


Page Intentionally Blank 


\section{SUMMARY AND CONCLUSIONS}

This report documents and presents the ORNL results for the OECD/NEA VENUS-2 MOX core blind benchmark study using HELIOS-1.4. The ORNL results are presented for three pincell calculations, and for the VENUS-2 core calculation.

In addition to the official ORNL benchmark results as delivered to OECD/NEA, this report presents some illustrative comparisons with experimental data for VENUS-2 pin powers. Also, the effects of improved modeling of the water region between the baffle wall and the barrel are presented and discussed.

The ORNL pin-cell $\mathrm{k}_{\text {inf }}$ calculations compare favorably to the results of the other institutions. The ORNL $\mathrm{k}_{\mathrm{eff}}$ calculation for the VENUS-2 core compares well to the critical experiment. The HELIOS-1.4 $\mathrm{k}_{\text {eff }}$ determination with the 190-neutron-energy-group library is within $0.1 \%$ of critical. There is a small trend observed toward slightly higher values of $\mathrm{k}_{\mathrm{eff}}$ as the number of groups is reduced to 89 and 34 . 
Page Intentionally Blank 


\section{REFERENCES}

1. B. C. Na and E. Sartori, Blind Benchmark on the VENUS-2 MOX Core Measurements, NEA/SEN/NSC/WPPR(99)2, OECD/Nuclear Energy Agency, Paris, May 1999.

2. B. C. Na, "Benchmark on the VENUS-2 MOX Core Measurements," NEA/NSC/DOC(2000)7, ISBN 92-64-18276-4, December 2000.

3. R. J. J. Stamm'ler and M. J. Abbate, Methods of Steady-State Reactor Physics in Nuclear Design, Academic Press, London, 1983.

4. J. J. Casal, R. J. J. Stamm'ler, E. A. Villarino, and A. A. Ferri, "HELIOS: Geometric Capabilities of a New Fuel-Assembly Program," Proceedings of the International Topical Meeting on Advances in Mathematics, Computations, and Reactor Physics, Pittsburgh, Pennsylvania, April 28-May 2, 1991, Vol. 2, p. 10.2.1 1-13.

5. E. A. Villarino, R. J. J. Stamm'ler, and A. A. Ferri, "HELIOS: Angular Dependent Collision Probabilities," Nuclear Science and Engineering, 112(16) (1992).

6. R. J. Ellis, "VENUS-2 Benchmark Calculations: ORNL Results with HELIOS-1.4," Presentations of preliminary and final ORNL results, Task Force On Reactor-Based Plutonium Disposition Meetings: TFRPD2 (November 1999) and TFRPD3 (June 2000), OECD/NEA Data Bank, Paris, France. (The final ORNL results were delivered electronically to the OECD/NEA Data Bank on February 1, 2000.) 
Page Intentionally Blank 
Appendix A

OECD/NEA SPECIFICATIONS 
Page Intentionally Blank 


\section{Appendix A. OECD/NEA SPECIFICATIONS}

\section{A.1 Appendix 2 from the OECD/NEA Specifications Document}

\section{Details to be provided about the Calculational Scheme Used}

(preferred format is WORD)

1. Name of participant

2. Establishment

3. Name of Code System(s) Used

4. Bibliographic References for the Codes Used

5. Origin of Cross Section Data (e.g. ENDF/B-VI, JEF-2.2, JENDL-3.2, etc.) (describe deviations of standard libraries, e.g. mix from different libraries, details)

6. Spectral Calculations and Data Reduction Methods Used (please describe your scheme, through a graph and explanatory words provide details about assumptions made)

a. resonance shielding: specify method(s) and specify energy range, and the nuclides (actinides, clad, fission products, oxygen, unresolved resonance treatment),

b. mutual shielding (overlapping of resonances),

c. fission spectra: specify whether only a single spectrum was used or a weighted mix from all fissile nuclides, explain procedure,

d. how was the $(n, 2 n)$ reaction treated?

e. weighting spectrum for scattering matrices, e.g. correction of the out-scatter and selfscatter terms considering the differences between the original weighting spectrum and realistic cell spectrum.

7. Number of Energy Groups Used in the different phases

8. Cell Calculation

a. type of calculation: (i.e. heterogeneous, homogeneous),

b. theory used: (diffusion, transport),

c. method used; (finite difference, finite elements, nodal, $\mathrm{Sn}$ (order), collision probability, Monte Carlo, J+/-, etc.),

d. calculation characteristics: (meshes, elements/assembly, meshes/pin, number of histories, multi-group, continuous energy, etc.). 
9. Other Assumptions and Characteristics

10. Comments Useful for Interpreting correctly the Results

\section{A.2 Response}

\section{Name of Participant:}

Ronald James ELLIS

(ellisrj@ornl.gov)

\section{Establishment:}

Oak Ridge National Laboratory (ORNL),

Reactor Physics Group,

Nuclear Analysis and Shielding Section,

Computational Physics and Engineering Division,

P.O. Box 2008, Oak Ridge, Tennessee, USA 37831

\section{Name of Code System Used:}

\section{HELIOS-1.4}

\section{Bibliographic Reference for the Codes Used:}

The following are open-literature references for HELIOS:

-R. J. J. Stamm'ler and M. J. Abbate, Methods of Steady-State Reactor Physics in Nuclear Design, Academic Press, London (1983).

—J. J. Casal, R. J. J. Stamm'ler, E. A. Villarino, and A. A. Ferri, "HELIOS: Geometric Capabilities of a New Fuel-Assembly Program," Proceedings of International Topical Meeting on Advances in Mathematics, Computations, and Reactor Physics, Pittsburgh, Pennsylvania, April 28-May 2, 1991, Vol. 2, p. 10.2.1 1-13.

-E. A. Villarino, R. J. J. Stamm'ler, and A. A. Ferri, "HELIOS: Angular Dependent Collision Probabilities," Nuclear Science and Engineering, Vol. 112, 16 (1992).

\section{Origin of the Cross-Section Data:}

The nuclear data libraries used were prepared by Studsvik Scandpower Inc. for 34 groups, 89 groups, and 190 groups. These nuclear data libraries for 34, 89, and 190 neutron energy groups are, respectively, hy3418-961a.dat, hy8918-961a.dat, and hy19048-961a.dat. These nuclear data libraries are all based on ENDF/B-VI, release 2, with revised data for U. The "a" indicates that corrections have been applied by Studsvik Scandpower to account for resonance capture effects in ${ }^{238} \mathrm{U}$. 


\section{Spectral Calculations and Data Reduction Method Used:}

(a) Resonance treatment including mutual shielding (overlap of resonances): HELIOS interpolates library data from tables of group resonance integrals (RIs) for homogeneous mixtures of the resonance isotopes with hydrogen. Nuclides other than hydrogen are represented by intermediate resonance factors $\lambda$ applied in the background cross section, $\sigma_{\mathrm{b}}$. Using this $\sigma_{\mathrm{b}}$ the RI can be deduced, and the group XS can be determined. In heterogeneous calculations, an equivalence of the flux with that of a homogeneous system is facilitated by adding an equivalence cross section, $\Sigma_{\mathrm{e}}$, to the background cross section. In HELIOS, the problem of the interaction of resonance isotopes is handled at two extremes: no interaction, and full interaction. For the full interaction, resonances of different isotopes overlap; such isotopes form a resonance category. A combination of the categories is called a resonance set. There are nine resonance sets available for HELIOS-1.4 calculations. For all these reported results, the HELIOS-1.4 cases were performed with the RES = 4 option (as recommended by Studsvik Scandpower representatives) in the RUN operator. RES signals a user-defined choice of resonance categories. RES $=4$ refers to the set with the three categories for ${ }^{238} \mathrm{U}$, for the rest of heavy metal (HM) nuclides, and for the non-HM nuclides.

(c) Fission spectra: For the fission spectrum calculation, a weighted mix of most of the fissionable nuclides is used $\left({ }^{234} \mathrm{U},{ }^{235} \mathrm{U},{ }^{236} \mathrm{U},{ }^{238} \mathrm{U},{ }^{237} \mathrm{~Np},{ }^{239} \mathrm{~Np},{ }^{236} \mathrm{Pu},{ }^{238} \mathrm{Pu},{ }^{239} \mathrm{Pu},{ }^{240} \mathrm{Pu},{ }^{241} \mathrm{Pu},{ }^{242} \mathrm{Pu}\right)$ and some average fission spectrum is added to represent the other fissionable actinides.

(d) The (n,2n) reaction: In the HM burnup calculations (chain), the (n,2n) reactions for ${ }^{232} \mathrm{Th}$,

${ }^{233} \mathrm{U},{ }^{238} \mathrm{U}$, and ${ }^{244} \mathrm{Cm}$ are considered. In addition, (n,3n) reactions are considered for ${ }^{232} \mathrm{Th},{ }^{233} \mathrm{U}$, ${ }^{234} \mathrm{U}$, and ${ }^{238} \mathrm{Pu}$.

\section{Number of Energy Groups Used in the Different Phases:}

The final ORNL VENUS-2 benchmark results from the cell calculations and from the core calculations were performed using 190 neutron energy groups. Calculations for interest, corroboration, and comparisons were also performed with 34 energy groups and 89 energy groups. See Item 10 of this benchmark summary for further details of the additional 34-group and 89-group results, compared to the official ORNL 190-group results.

\section{Calculations:}

(a) Type of calculation: heterogeneous

(b) Theory used: transport theory

(c) Method used: Current coupling (between structures) and collision probability (within structures); this is known as the CCCP methodology.

(d) Calculation characteristics: A very detailed model was used for the final ORNL VENUS-2 core representation. The "windmill" pattern was used in modeling the moderator region surrounding each fuel pin. Explicit fuel-cladding gaps were used in the model of the $\mathrm{UO}_{2}$ fuel pins, while the MOX fuel pins did not have a fuel-cladding gap. For the core calculations, the current coupling parameter $\mathrm{k}=4$ was used as recommended.

\section{Other Assumptions and Characteristics:}

The final ORNL VENUS-2 HELIOS model (from which the ORNL reported results come) includes the following confirmed assumptions: The Pyrex assemblies are modeled with void within the inner radius of the Pyrex and void between the outer Pyrex and inner cladding radii. 
Water surrounds the Pyrex assembly outer cladding radius. The central square hole within the inner baffle wall is modeled to be entirely water. Spectral reflection boundary conditions are applied at the symmetry boundaries. For the HELIOS core calculations, the VENUS-2 model assumes a very small specific power level of $0.0009141 \mathrm{~W} / \mathrm{gHE}$.

\section{Comments Useful for Correctly Interpreting the Results:}

For the tables for the CELL CALCULATIONS, the isotopes ${ }^{234} \mathrm{U}$ and ${ }^{236} \mathrm{U}$ were added by me to those in the sample tables from the VENUS-2 benchmark specifications, Appendix 3 of NEA/SEN/NSC/WPPR(99)2. These uranium isotopes are necessary for the complete reaction rate details; ${ }^{238} \mathrm{Pu}$, on the other hand, is not needed, as it is not explicitly in any of the modeled fuel compositions. The reaction rates presented in the tables are normalized in the cell calculation tables such that the sum (over all energy groups and for all the participating nuclides) of the fission rates for each case is numerically $1.87 \times 10^{8}$. For the absorption rates and fission rates, the three energy groupings chosen are closest to those requested in the benchmark specifications: these are defined as neutron energies above $4.881 \mathrm{keV}$, between $4.881 \mathrm{keV}$ and $3.928 \mathrm{eV}$, and below $3.928 \mathrm{eV}$.

For the VENUS-2 CORE CALCULATIONS, the relative pin power distributions are normalized such that the total of 640 fuel pins in one-quarter of the core have a total sum of relative pin powers of 640. The tabulated pin powers represent one-eighth of the core, but with the full "diagonal sites" (numbers 6, 13, 21, 30, 38, 49, 61, 73, 85, and 100) fuel pins included.

All of the cell calculations and core calculations presented in my final VENUS-2 benchmark results are from HELIOS-1.4 cases using 190 neutron energy groups. The results obtained using 89 and 34 neutron energy group libraries with HELIOS-1.4 are similar with a few differences. Some of the interesting data are shown below from different calculations for the same VENUS-2 model (the final one) using different numbers of neutron energy groups. One can see that $\mathrm{k}_{\mathrm{eff}}$ is very similar for 190 and 89 groups, but that the $\mathrm{k}_{\mathrm{eff}}$ value for 34 groups is larger.

\section{Core calculations $\left(\mathbf{k}_{\text {eff }}\right)$ as function of number of energy groups}

\begin{tabular}{cc}
\hline $\begin{array}{c}\text { Number of energy } \\
\text { groups }\end{array}$ & $\begin{array}{c}\mathbf{k}_{\text {eff }} \text { (as calculated } \\
\text { with HELIOS-1.4) }\end{array}$ \\
\hline 190 & 0.99870 \\
89 & 0.99907 \\
34 & 1.00150 \\
\hline
\end{tabular}

The relative pin powers (for certain pin locations) from three different HELIOS-1.4 cases for the same final VENUS-2 model but using 190, 89, and 34 neutron energy group nuclear data libraries are shown below. The pin locations are identified by the pin numbering scheme (1-325) as shown at TFRPD2. The chosen pin locations are seemingly interesting places at the inner and outer baffle walls, at the position of the hottest observed fuel pin power level, near some of the Pyrex sites, and in the center of the fuel array. 
Comparison of certain relative pin power values from core calculations with different number of energy groups

\begin{tabular}{rccc}
\hline & 190 groups & 89 groups & 34 groups \\
\hline 1 & 1.04232 & 1.03684 & 1.03189 \\
5 & 1.15284 & 1.14779 & 1.14311 \\
6 & 1.29802 & 1.29296 & 1.28756 \\
23 & 1.27493 & 1.27130 & 1.26559 \\
34 & 1.34733 & 1.34475 & 1.33970 \\
68 & 1.29560 & 1.29428 & 1.29042 \\
69 & 1.30816 & 1.30712 & 1.30384 \\
85 & 1.17368 & 1.17340 & 1.17192 \\
100 & 0.91350 & 0.91320 & 0.91290 \\
101 & 1.54459 & 1.54345 & 1.54093 \\
229 & 0.78515 & 0.78708 & 0.79075 \\
311 & 0.42566 & 0.42690 & 0.43035 \\
325 & 0.21713 & 0.21682 & 0.21796 \\
\hline
\end{tabular}

Cell calculations $\left(k_{\text {inf }}\right)$ for different number of energy groups

\begin{tabular}{cccc}
\hline $\begin{array}{c}\text { Number of energy } \\
\text { groups }\end{array}$ & $\mathbf{3 . 3} \mathbf{U O}_{\mathbf{2}}$ & $\mathbf{2 . 0 / 2 . 7} \mathbf{M O X}$ & $\mathbf{4 . 0} \mathbf{U O}_{\mathbf{2}}$ \\
\hline 190 & 1.40847 & 1.26254 & 1.34333 \\
89 & 1.40677 & 1.26279 & 1.34152 \\
\hline
\end{tabular}


Page Intentionally Blank 


\section{INTERNAL DISTRIBUTION}

$\begin{aligned} 1 . & \text { B. B. Bevard } \\ 2 . & \text { S. M. Bowman } \\ 3 . & \text { B. L. Broadhead } \\ 4 . & \text { R. L. Childs } \\ 5 . & \text { E. D. Collins } \\ 6 . & \text { B. S. Cowell } \\ 7 . & \text { M. D. DeHart } \\ 8 . & \text { F. C. Difilippo } \\ 9 . & \text { K. R. Elam } \\ 10-14 . & \text { R. J. Ellis } \\ 15 . & \text { S. E. Fisher } \\ 16 . & \text { I. C. Gauld } \\ 17-21 . & \text { J. C. Gehin } \\ 22 . & \text { S. R. Greene } \\ 23 . & \text { T. W. Horning } \\ 24 . & \text { D. T. Ingersoll } \\ 25 . & \text { H. T. Kerr } \\ 26 . & \text { M. A. Kuliasha }\end{aligned}$

\author{
27. R. A. Lillie \\ 28. S. B. Ludwig \\ 29. G. E. Michaels \\ 30. D. L. Moses \\ 31. C. V. Parks \\ 32-36. R. T. Primm III \\ 37. W. J. Reich \\ 38. I. Remec \\ 39. C. E. Sanders \\ 40. D. J. Spellman \\ 41. C. C. Southmayd \\ 42. J. C. Wagner \\ 43. R. M. Westfall \\ 44. G. L. Yoder, Jr. \\ 45. Central Research Library \\ 46-47. ORNL Laboratory Records (OSTI) \\ 48. ORNL Laboratory Records (RC)
}

\section{EXTERNAL DISTRIBUTION}

49. M. L. Adams, Department of Nuclear Engineering, Texas A\&M University, Zachry 129, College Station, TX 77843

50. D. Alberstein, Los Alamos National Laboratory, MS-K551, P.O. Box 1663, Los Alamos, NM 87545

51. P. Alekseev, Russian Research Center "Kurchatov Institute," Department of Physical and Technical Research of Advanced Reactors, Kurchatov Square, 1, 123182 Moscow, Russia

52. J. F. Baker, Office of Fissile Materials Disposition, U.S. Department of Energy, NN-63, 1000 Independence Avenue SW, Washington, DC 20585

53. J. B. Briggs, Idaho National Environmental and Engineering Laboratory, P.O. Box 1625-3855, Idaho Falls, ID 83415-3855

54. M. S. Chatterton, U.S. Nuclear Regulatory Commission, Office of Nuclear Reactor Regulation, MS O10 B3, Washington, DC 20555-0001

55. K. Chidester, Los Alamos National Laboratory, MS-E502, P.O. Box 1663, Los Alamos, NM 87545

56. R. H. Clark, Duke/Cogema/Stone \& Webster, 400 South Tyrone Street, WC-32G, P.O. Box 1004, Charlotte, NC 28202

57. W. Danker, U.S. Department of Energy, NN-62, 1000 Independence Avenue SW, Washington, DC 20585 
58. M. Delpech, CEN Cadarache, SERSI/LECC, Bat. 212, F-13108, St. Paul les Durance Cedex, France

59. P. J. D'Hondt, SCK-CEN, 200 Boeretang, B-2400, Mol, Belgium

60. N. Fletcher, Office of Fissile Materials Disposition, U.S. Department of Energy, NN-63, 1000 Independence Avenue SW, Washington, DC 20585

61. T. Gould, Lawrence Livermore National Laboratory, P.O. Box 808, MS-L186, Livermore, CA 94551

62. K. Hesketh, British Nuclear Fuels plc, Research and Technology Department, B709, Springfields, Salwick, Preston, Lancashire, PR4 OXJ, U.K.

63. U. Hesse, Gesellschaft fuer Anlagenund Reaktorsicherheit Forschungsgelaende, Postfach 1328, Garching, Germany

64. L. Holgate, Office of Fissile Materials Disposition, U.S. Department of Energy, NN-60, 1000 Independence Avenue SW, Washington, DC 20585

65. L. Jardine, Lawrence Livermore National Laboratory, P.O. Box 808, MS-L166, Livermore, CA 94551

66-70. A. Kalashnikov, Institute of Physics and Power Engineering, 1 Bondarenko Square, Obninsk, Kaluga Region, Russia 249020

71. M. A. Kalugin, Russian Research Center "Kurchatov Institute," Institute of Nuclear Reactors, VVER Division, VVER Physics Department, 123182, Kurchatov Square, 1, Moscow, Russia

72. U. Kasemeyer, Paul Scherrer Institute (PSI), CH-5232 Villigen, Switzerland

73. K. Kitagawa, Representative Director, Nuclear Fuel Industries Ltd., Europe Office, 11 rue Christophe Colomb, 75008, Paris, France

74. D. E. Klein, Associate Vice Chancellor for Special Engineering Programs, The University of Texas System, 210 West Sixth Street, Austin, TX 78701

75. R. W. Lee, Office of Nuclear Reactor Regulation, MS O10 B3, U.S. Nuclear Regulatory Commission, Washington, DC 20555-0001

76. T. Maldague, Belgonucleaire S. A., Avenue Ariane 4, B-1200, Bruxelles, Belgium

77. M. Mattes, Universitaet Stuttgart, Institut fuer Kernenergetik und Emergiesysteme, Postfach 801140, D-70550, Stuttgart 80, Germany

78. B. C. Na, OECD/NEA Data Bank, 12 Bd des Iles, 92130 Issy-les-Moulineaux, France

79. S. Nesbit, Duke/Cogema/Stone \& Webster, 400 South Tryon Street, WC-32G, P.O. Box 1004, Charlotte, NC 28202

80. J. O. Nulton, Office of Fissile Materials Disposition, U.S. Department of Energy, NN-61, 1000 Independence Avenue SW, Washington, DC 20585

81. J. M. Parotte, Paul Scherrer Institute (PSI), CH-5232 Villigen, Switzerland

82. S. L. Passman, Booz-Allen \& Hamilton, 555 13th Street, NW, No. 480E, Washington, DC 20004

83-87. A. Pavlovitchev, Russian Research Center "Kurchatov Institute," Institute of Nuclear Reactors, VVER Division, VVER Physics Department, 123182, Kurchatov Square, 1, Moscow, Russia

88. K. L. Peddicord, Associate Vice Chancellor, Texas A\&M University, 120 Zachry, College Station, TX 77843-3133

89. D. Porsch, Siemens Power Generation Group (KWU), Department NBTI, Postfach 3220, D-91058, Erlangen, Germany

90. G. Radulescu, Framatom Cogema Fuels, 1261 Town Center Drive, MS-423, Las Vegas, Nevada 89143

91. W. D. Reece, Texas A\&M University, Department of Nuclear Engineering, Zachry 129, College Station, TX 77843-3133

92. E. Sartori, OECD/NEA Data Bank, 12 Bd des Iles, 92130 Issy-les-Moulineaux, France 
93. U. Shoop, Office of Nuclear Reactor Regulation, MS O10 B3, U.S. Nuclear Regulatory Commission, Washington, DC 20555-0001

94. E. Siskin, Office of Fissile Materials Disposition, U.S. Department of Energy, MD-1/2, 1000 Independence Avenue SW, Washington, DC 20585

95. J. Thompson, Office of Fissile Materials Disposition, U.S. Department of Energy, MD-4, 1000 Independence Avenue SW, Washington, DC 20585

96. K. Van der Meer, Studie Centrum voor Kernenergie, SCK-CEN, 200 Boeretang, B-2400, Mol, Belgium

97. M. Williams, Louisiana State University, Baton Rouge, LA 70803-5820

98. T. Wolf, Siemens/KWU, Department NBTS, Postfach 3220, Freyeslebenstr. 1, D-91050, Erlangen, Germany

99. A. Worrall, British Nuclear Fuels plc, MOX Design and Licensing, B709 Research and Technology Department, Springfields, Salwick, Preston, Lancashire, PR4 OXJ, U.K.

100. W. Zwermann, Gesellschaft fuer Anlagenund Reaktorsicherheit (GRS) mbH, Forschungsgelaende, D-85748, Garching, Germany 